\title{
ERKEN ÇOCUKLUKTA PEYGAMBER TASAVVURU VE DIN EĞitiMi: FENOMENOLOJIK BIR ARAŞTIRMA*
}

\author{
Aslıhan ATiK** \\ E-mail: aslihanatik@cu.edu.tr \\ ORCID ID: https://orcid.org/0000-0002-0773-8927
}

Citation/@: Atik, A. (2021). Erken çocuklukta peygamber tasavvuru ve din eğitimi: Fenomenolojik bir araştırma. Türkiye Din Eğitimi Araştırmaları Dergisi, 12, 245-282.

DOI Number: https://doi.org/10.53112/tudear.1000477

Öz

Bu araştırmada, 4-6 yaş dönemindeki çocukların peygamber ile ilgili düşünceleri hakkında bilgi edinmek ve bu çerçevede din eğitimi açısından pedagojik bazı ilkelere ulaşmak amaçlanmıştır. Araştırmada, nitel araştırma yöntemlerinden fenomenolojik desen kullanılmıştır. Araştırmanın çalışma grubunu 4-6 yaş arasındaki 11 çocuk oluşturmuştur. Araştırma sonucuna göre bu dönemde çocukların Allah, Kur'an ve dua ile ilgili eksik ve tutarsız olsa da bir düşünce geliştirebildikleri ama peygamber/ler ile ilgili herhangi bir düşünce geliştiremedikleri, bazı çocukların peygamberi Allah olarak anladıkları tespit edilmiştir. Bu bağlamda erken çocukluk döneminde peygamber/ler ile ilgili yapılacak din eğitimi çalışmaları, ilkokul yıllarında gerçekleştirilecek anlatımlar için hazırlık niteliği taşımalıdır. Çalışmamızın en önemli bulgusu, din eğitimi bu dönemde bilgi aktarımından ziyade çocuklara rol model olabilecek, duyguları harekete geçirecek, sevgi temelli bir yaklaşım içerisinde ele alınmasının gerekliliğidir.

Anahtar Kelimeler: Din eğitimi, Erken çocukluk, Dini gelişim alanı, Kur’an, Peygamber.

Etik Beyan: Bu çalışmanın hazırlanma sürecinde bilimsel ve etik ilkelere uyulduğu ve yararlanılan tüm çalışmaların kaynakçada belirtildiği beyan olunur. Makale en az iki hakem tarafından incelenmiş, Turnitin kullanılarak benzerlik raporu alınmış ve araştırma/yayın etiğine uygunluğunu teyit edilmiştir. Ethical Statement: It is declared that scientific and ethical principles have been followed while carring out and writing this study and that all the sources used have been properly cited. The article was reviewed by at least two referees, a similarity report was obtained using Turnitin, and compliance with research/publication ethics was confirmed.

Etik Kurulu Kararı: Bu araştırma için Çukurova Üniversitesi, Sosyal ve Beşerî Bilimler Alanında Bilimsel Araşrma ve Yayın Etik Kurulu'undan 06.09.2021 tarihinde (Karar No: 2) izin alınmıştır (Bkz. Ek 5). 


\title{
PROPHET CONCEPTION AND RELIGIOUS EDUCATION IN EARLY CHILDHOOD: A PHENOMENOLOGICAL STUDY
}

\begin{abstract}
Abu Bakr belonged to a branch of the tribe of Quraysh, by the name of Benī Taym. This little sub-tribe consisted of a very few number of people. The duty of ashnaq, that is, the resolution of the blood feuds and determination of ransom was performed by this tribe in the era of Jahiliyyah. As one of the first Muslims Abu Bakr helped Muhammed (pbuh) from the earliest days. Some of his most important contributions of this period are his efforts to spread the religion, and his purchasing of slaves and consequently freeing them. He was well known for his limitless generosity for the cause of the God's religion. He was named as-siddiq after the Mīrāj. His name is mentioned in the Qoran implicitly. Along with these characteristics, Abu Bakr was also one of the most eventempered among the sahaba. Being Prophet's companion in the cave and during the Hijrah, and being his most confident consultant and Prophet's substitute in the mihrab during illness, earned him a special place in Prophet's regard. He was repeatedly praised by the Prophet himself and his companions. His relations with other companions are mostly modeled on his relationship with the Prophet himself.
\end{abstract}

Keywords: Religious education, Early childhood, Field of religious development, Quran, Prophet.

\section{Giriş}

Din eğitiminde hangi içeriğin, niçin ve nasıl bir kurgu ile anlatılması gerektiğiyle ilgili arayışlara en güçlü temellendirmeler gelişim psikolojisi alanından gelmektedir (Copley, 2008, s.76; Roos, Ledema ve Miedema, 2003, s. 165). Salt teolojik kaygılarla ayetler ezberleterek, ayrıntılı ilmihal açıklamaları yaparak ve entelektüel dini bilgiler yükleyerek sağlıklı bir din eğitiminin gerçekleştirilemeyeceği son dönemlerde en çok tartışılan konular arasındadır. İslam din eğitimi bağlamında teolojik temellendirmeler de bizi insanın varoluşsal değeri ve dinin insan için olduğu bilgisine ulaştırmaktadır (Yazır, 2012, ss. 255257). Bu bağlamda din eğitiminin en nihai amacı, dini bilgi edinme/edindirme sürecinin çok daha ötesinde gelişimsel ihtiyaçlarına göre dini içeriğin kişiye ne sunabileceğini araştırmasıdır. Odağında insanın olduğu din ve manevi eğitim yaklaşımları bu yönüyle psikolojik, teolojik ve pedagojik bütünlük taşıyan model ve yaklaşımlar üretmek durumundadır. Örneğin son yıllarda Batı toplumlarında ortaya konulan Montessori Yaklaşımı (Bkz. Montessori, 1965) ve Goldman'ın Yaşam Merkezli Din Eğitimi Yaklaşımı (Bkz. Goldman, 1964) çocuğun ilgi, merak ve gelişim yeterliliği doğrultusunda yaşadığı hayatın içinde güncel karşılığı olan din ve maneviyat eğitiminin önemine vurgu yapmaktadır. Sistematik ve teorik olarak dine ait içeriğin dışarıdan çocuğa aktarılması veya 
çocuğun bunları olduğu gibi almasına dayanan bankacı modelden farklı olarak çocukların gelişim düzeylerine uygun bir çevrede, kendi yaşam deneyimlerinin temel alındığı bu yaklaşımlarda çocuğun gelişim alanları ve hızları dini içeriği dizayn etmede en temel belirleyicidir.

Gelişim psikolojisi, döllenmeden itibaren yaşam boyunca bireyi fiziksel, bilişsel, sosyalduygusal, kişilik, ahlaki ve dini gelişim alanlarında incelemeye ve anlamaya çalışır. Her ne kadar gelişimin birçok alanı çizgisel olarak ilerlemese ve karmaşık bir nitelik taşısa da gelişim dini gelişim alanı başta olmak üzere bilişsel, kişilik, ahlaki gelişim ile ilgili önemli veriler sunar.

\section{Erken Çocuklukta Dini Gelişim ve Peygamber Tasavvuru}

Erken çocukluk döneminde ${ }^{1}$ gelişim yaşamın hiçbir evresinde olmadığı kadar kritik bir nitelik taşımaktadır. Çocuğun vücudunu yönetebilme becerisi kazandığı, etrafında onu kuşatan dünya ile ilgili ilk bilişsel şemalarını oluşturduğu, kendisinin ne olduğuyla ilgili düşüncelerin gelişmeye başladığı, çevresine uyum sağlamaya çalıştığı doğal olarak öğrenmenin oldukça hızlı gerçekleştiği bu gelişim evresi karmaşık ve hassas bir dönemdir (Senemoğlu, 2012; Wilson, 1991, ss. 224-226). Böylesine çok boyutlu, kompleks ve dinamik bir sürecin içerisinde çocuğun dine ait duygularının ve düşüncelerinin de "gelişen" bir olgu olarak ele alınması gerektiği son dönem uygulamalı alan araştırmalarında ortaya konulmaktadır (Bunge, 2006; Coles, 1990; Elkind, 1971; Goldman, 1964; Harms, 1944; Heller, 1986; Schweitzer, 2006). Çocuk bu dönemde fiziksel, bilişsel, dil, kişilik, sosyal ve ahlaki gelişimde olduğu gibi dinî gelişim alanında da ilerleme içerisindedir (Crapps, 1986, ss. 164-171). Kalıtımla ilgili bir yönünün olup olmadığını tartışmanın dışında tutarsak (Bkz. Vergote, 1969) çocuğun içine doğduğu toplumda karşılaştığı sosyal bir fenomen olan dine karşı diğer gelişim alanlarının ilerlemesi oranında geliştirdiği duygu ve düşünceler "çocuğun dini gelişim alanı" olarak tanımlanabilir. Özellikle bilişsel ve dil gelişimi alanlarındaki ilerlemeler sonucunda dış dünyada deneyimlediği şeyleri zihninde sembollerle temsil etmeye başlayan çocuk bu dönemde başta aile ortamı olmak üzere yakın çevresinde Allah ve dolayısıyla onunla ilgili birçok olgu ve olayla karşılaşır. íbadet eden birini görmesi, okunan ezanı dinlemesi, camiyi fark etmesi, insanların günlük konuşmalarında dine ait ifadeleri duyması, Kur'an okuyan birine şahit olması, ramazan ayını yaşaması, kurbanbayramına katılması gibi birçok farklı durum çocukta Allah ve dolayısıyla dinle ilgili duygu ve düşüncelerin oluşmasını ve gelişmesini destekler. Dini düşüncenin gelişimi ile ilgili yapılan araştırmalar, çocukların yaşla birlikte düşüncelerindeki niceliksel artışın yanında, düşüncelerinin nitelik olarak da değiştiğini ve çeşitli aşamalardan geçtiğini ortaya koymaktadır. Elbette her çocuk aynı yaşta aynı gelişim düzeyine ulaşmaz. Bu onun zihinsel gelişimine, motivasyonuna ve diğer pek çok faktöre bağlıdır (Cox, 1966, ss. 35-37). Örneğin Vianello'ya göre, çocukların Tanrı anlayışı onların zihinsel kapasiteleri

1 Bu araştırmada 4-6 yaş arası “Erken Çocukluk Dönemi” olarak ele alınacaktır. 
tarafından etkilenmektedir. Çocuğun Tanrı hakkında oluşturduğu zihinsel şema ile diğer herhangi bir kavram hakkında oluşturduğu zihinsel şema aynıdır. Dolayısıyla çocuğun zekâsının yapısal özellikleriyle ilgili sınırılıkları çocuğun tanı hakkındaki düşüncelerini de etkilemesi söz konusudur (Vianello, Tamminen ve Ratcliff, 1992, s. 57). Bireysel farklılıklar olmakla beraber genelde tüm çocukların birbirine benzer bu basamaklardan geçtiği de araştırmaların ortaya koyduğu bir husustur (Cox, 1966, ss. 35-37).

Dini, insanın hayat boyu süren arayışı olarak ele alan Elkind erken çocukluk dönemi dini gelişimi "Temsil Arayışı” olarak nitelendirir. Varlığı kabul edilen yaratıcı ile ilgili arayışların başladığı bu evrede soyut düşünme gelişmediği için çocuk gözleriyle gördüğü, elleriyle dokunabildiği kısacası bir şekilde deneyimleyebildiği şeylerin varlığından hareket ederek düşünce geliştirir. Doğal olarak Yaratıının/Tanrının nasıl bir şekli olduğu, neye benzediği, nerede yaşadığı, neden görünmediği gibi şeylere ilgi gösterirler. Bununla birlikte dil ve zihinsel/entellüktüel yeterliliklerinin ilerlemesi, işaret ve sembollerle düşünebilmeye başlaması Elkind'e göre beraberinde çocukta Yaratıcıyı temsil edecek semboller aradığı ve yaratıcıyı bu sembollerle ifade ettiği süreci başlatır (Elkind, 1970, ss. 36-38). Bu dönemde çocuğun arayışlarına en güçlü cevabı veren içinde yaşadığı toplumda hâkim olan dinin sunduğu içeriklerdir. Din çocuğa sadece bir Tanrı düşüncesi sunmaz aynı zamanda Tanrı ile nasıl iletişim kurabileceğini, diğer insan/lar ve eşya ile ilişkisinde nelere dikkat ederse O’nun hoşnutluğunu kazanabileceği gibi kapsamı geniş bir sistem sunar (Elkind, 1971, s. 36).

Çocuktaki ilk inanç anne ve diğer bakım verenlerler ilişki kurduğu sırada, temel güven duygusu ile başlar (Erikson, 1963). Yaşama gözlerini büyük bir arayış ile açan çocuk hayatta kalmak için bir başkasına intiyaç duymaktadır. Doğal olarak kendisine bakım veren kişiye/annesine karşı ilk inanma deneyimini/inancını geliştirir. Çocuğun ilk inancını geliştirme sürecinde yaşadığı olumlu ya da olumsuz tecrübeler onun sonraki hayatında geliştireceği inançlar ve kuracağı ilişkiler açısından elbette ki önemlidir (Boojamra, 1984, s.21). Dini gelişim alanını "inanç" kavramından hareket ederek açıklamaya çalışan Fowler inancın bütün insanlarda ortak bir özellik olduğunu söyler (Fowler ve Dell, 2006). Genel olarak kişinin yaşamına tutarlılık kazandıran, insanlarla güvene dayalı ilişkiler kurmasına temel olan, bütünü kavramasına destek sağlayan ve hayatın zorlukları ile mücadelede güç veren bir olgu olarak inancı tanımlar. Fowler inancın kişide nasıl geliştiğini anlamaya çalışırken Goldman (Bkz. Goldman, 1963) gibi sadece bilişsel gelişimi merkeze almamış, daha kapsamlı bir bakış açısı içerisinde inanç gelişimini açıklamıştır. Ona göre inanç gelişimini anlayabilmek için cinsiyet ve ırk faktörleri de dâhil olmak üzere biyolojik olgunlaşma, duygusal gelişim, psiko-sosyal tecrübe ve dini-kültürel semboller, manalar ve pratikleri dikkate almanın yanında bunların karşılıklı birbirini etkileyen doğalarıda hesaba katılmalıdır. Fowler, eğer inancın bu yapısı iyi anlaşıırsa bir aşamadan diğerine doğru inanç gelişiminin otomatik ve ardışık ilerlemesinin aslında birçok etkene bağlı olduğunun da anlaşılabileceğini ifade etmiştir (Fowler ve Dell, 2006). Fowler erken çocukluk ile ilgili bu 
dönemi "Sezgisel-Yansıtıcı İnanç" olarak ele alır ve dönemin en temel özelliklerini fiziksel, bilişsel, dil ve kişilik gelişimi alanlarındaki ilerlemeler ile ilişkilendirerek açıklar. Bu yönüyle Fowler'in inanç gelişimi ardışık ve hiyerarşik bir yapı sergiler (Fowler, 1974, s. 213). Erken çocukluk ve öncesindeki 0-2 yaş dönemi sonraki inanç aşamaları için her ne kadar belirleyici olmasa da bu aşamaların sağlıklı geçirilmesi önemlidir (Fowler, 2004; Oruç, 2013; 2014; 2019). Çocuğun bireysel oyun döneminden aynı şeyi aralarında çok etkileşim kurmadan yaptıkları paralel oyun dönemine geçmesini, sembolik düşünme ve temsili oyunlar oynayabilmesini önemli gelişimsel ilerlemeler olduğunu ifade eden Fowler, bütün bunların kişilik gelişimi açısından da önemli olduğunu söyler. Bu dönemin, utanç ve şüphe karşısında özerkliği keşfetmesinin sonunda irade gelişimini sağlaması açısından da çocuk için temel teşkil ettiğine dikkat çeker (Fowler ve Dell, 2006). Bu dönemde basit görüş açısına sahip olan çocuk, işlemleri tersine çevirme gibi temel düşünme becerilerini yapamadığı için sebep-sonuç ilişkilerini de iyi anlayamaz. Olayları düzensiz bir içerikte yeniden yapılandırır. Fantezi ve hayal ürününü gerçekten ayırt edemez. Henüz gelişmemiş olan bilişsel benmerkezcilik sebebiyle kendi bakış açısını diğerlerininkinden tutarlı bir şekilde ayıramazlar. Doğal olarak bu aşamada inanca, mantıksal düşünce yerine hayal gücü hâkimdir (Gottlıeb, 2012). Dolayısıyla bu dönemde inanç yapılanmaları sembollere, görünür güç ve cisimlere dayandırılır (Fowler and Dell, 2006).

Çocukluk dönemi dini gelişimi şekillendiren önemli unsurlardan birinin duygular olduğunu söylemek mümkündür. Hayatın bu evresinde duygular çocuk için oldukça önemli rol oynar (Wallinga ve Skeen, 1988, ss. 45-46). Düşünme becerilerindeki devam eden gelişim henüz yetişkinlikteki düzeyde olmadığı için doğal olarak duygular ön plandadır. Özellikle çocukların ne öğrendiklerinden ziyade nasıl öğrendiklerinin daha önemli olduğu bu dönemde (Lee, 1988) düşüncelere ve davranışlara yön veren temel unsur duygulardır ve çocuk-bu gelişim döneminde duygularını tanımak ve onlarla baş etmek durumundadır. Dini gelişim alanını çocuğun duygularını ve hayallerini merkeze alarak açıklamaya çalışan Harms bunu dinin doğasındaki farklılığın bir gerekçesi olarak da temellendirmiştir (Harms, 1944). "Peri Masalı Aşaması” olarak tanımladığı bu dönemde çocukların Allah'a karşı saygı ve korku ile birleşik bir duygu hissettiğini ve bu duyguları da masallardaki sembollerle ifade ettiğini çalışmasında ortaya koymuştur. Riccards da benzer bir şekilde bu dönemi Masalımsı Basamak (Fairy Tale, 3-6) olarak tanımlamıştır. Bu dönemde Tanrı çocuklar tarafından "yaşlı kişi, baba ya da sihirli güçlere sahip çocuk" gibi terimlerle ifade edilir. Yine bu evrede çocuklar arasında belirli bir din ya da mezhep fikrinden ziyade evrensel bir dini anlayış vardır ve bu dönemde dua daha çok sihir ile alakalı işlerin olmasında bir istek olarak görülür (Riccards, 1978, ss. 113-114).

Erken çocukluk dönemi dini gelişim alanını ele alış tarzlarında farklılıklar olmakla beraber her yaklaşım bu dönemin bir yönünü açıklamasından dolayı önemli veriler sunmaktadır. Düşüncelerin dağınık olması, duyguların önem taşıması, hayallerin baskın olması erken çocukluk döneminde öne çıkan temel dini gelişim özellikleri olduğu söylenebilir. Elbette ki 
bu yaklaşımların bütünlüklü bir şekilde ele alınmasının yanında çocukların Allah ile ilgili geliştireceği düşünce/fikirlerin, kısacası Allah tasavvurlarının anlaşılması da önemlidir. Çünkü Allah ile ilgili düşünceler çocuğun dini gelişim alanını şekillendiren en temel unsurdur (Torrance ve Torrance, 1988, s.233). Merkezi bir öneme sahip olan Allah tasavvuru aynı zamanda çocukluk döneminde inşa edilmeye başlayan en önemli tasavvurlardan birisidir (Yavuz, 2007, s. 10). Tanrı tasavvuru, kişinin bebekliğinden itibaren, zekâ gelişimine, edinmiş olduğu bilgi ve yaşantısına göre, Tanrı'yı zihninde canlandırması, biçimlendirmesi ve anlamlandırması şeklinde tanımlanmaktadır (Peker, 1993, s. 51). Çocuklar daha ilk yıllarından itibaren evrenin Tanrı tarafından yaratıldığını kabul ederler. Tanrı bir Süpermen'dir ve bütün yarattıkları harikuladedir. Vienallo yaptı̆̆ araştırmasında altı-yedi yaşındaki çocukların, Tanrıyı bir yaratıcı olarak anladıklarını ortaya koymuştur. Bununla beraber yaratma eylemi, yoktan bir şeyi yaratma olarak değil mevcut bir şeyden yeni bir şey ortaya koyma şeklinde anlaşılmaktadır. Ancak ilk çocukluk yıllarında bu yaratma eylemi son dönemde olduğu kadar açık ve net değildir (Vianello, Tamminen \& Ratcliff, 1992, ss. 59-60).

Çocukların gelişimsel basamaklarına göre Tanrı inancını araştıran Baker ve Koppe (1959) ile Wright ve Koppe (1964) 4-5 yaşlarında çocukların hala Tanrıyı bir yere yerleştirme eğiliminde olduklarını ve genellikle Tanrının gökyüzünde ya da kendi içlerinde olduğuna inandıklarını ifade etmiştir. Tanrı güçlü bir şekilde tabiatla, kuşlarla, çiçeklerle, kar ve yağmurla ilişkilidir. Bazı çocuklar Tanrının kendilerini geceleyin koruduğuna ve onları gözetlediğine, kötülük yaptıklarında kendilerini cezalandıracağına inanmaktadırlar. 6-7 yaşlarında ise Tanrı evrenin, ağaçların, hayvanları, yıldızların ve insanların planlayıcısıdır. Tanrı antropomorfik ${ }^{2}$ olarak tasvir edilir. Çoğu çocuklara göre Tanrı "her yerdedir." Hala bazıları Tanrıyı görmek ve onunla konuşmak ister (Havighurst ve Keating, 1971).

Çocukluk döneminde -Tanrı tasavvurunun dışında- oluşan muhtemelen önemli tasavvurlardan bir diğerinin Peygamber/ler ile ilgili olduğu söylenebilir. Çünkü İslam din eğitimi bağlamında $\mathrm{Hz}$. Peygamber'in ve diğer peygamberlerin öğretimi oldukça önemlidir. Bu konuda literatürde doğrudan erken çocukluk dönemi peygamber algısını inceleyen çalışmalar sınırlıdır. Konu daha çok uygulamalı çalışmalar yerine felsefi açıklamalar şeklinde ele alınmıştır.

\section{Araştırmanın Amacı}

Araştırmanın amacı erken çocukluk dönemindeki 4-6 yaşındaki çocukların peygamber/ler ile ilgili düşünceleri hakkında bilgi edinmek ve elde edilen verilerden peygamberlerin nasıl

2 Yaklaşık altı yaşına kadar çocuklar genellikle Tanrıyı bir insan ve eylemlerini de bir insan eylemleri gibi düşünürler. Bu yaştan sonra Tanrıyı daha manevi açıdan düşünmektedirler. Altı yaşından on bir yaşına kadar çocuklar Tanrıyı daha spiritual bir varlık olarak algılar. Ayrıntılı bilgi için bkz., (Vergote, 1969. s. 278; Vianello, Tamminen \& Ratcliff, 1992). 
anlatılması gerektiği ile ilgili pedagojik ilkelere ulaşmaktır. Bunun için aşağıdaki soruya cevap aranmaya çalışılmıştır:

- Çocukların peygamber/ler ile ilgili düşünceleri nedir?

\section{Yöntem}

\subsection{Araştırmanın Modeli}

Erken çocukluk dönemi 4-6 yaşındaki çocukların peygamber/ler ile ilgili düşüncelerini derinlemesine incelemenin amaçlandığı bu araştırma nitel bir bakış açısı ile yürütülmüştür. Anlam arama çabasının peşinde olan nitel araştırma, bireylerin yaşantılarını nasıl yorumladıklarını, dünyalarını nasıl yapılandırdıklarını ve deneyimlerine ne anlam yüklediklerini kavramaya çalışır (Ersoy ve Saban, 2019, ss. 4-5). Bu araştırmada "bireysel deneyimlerin oluşturduğu bakış açısını kendine hareket noktası yaptığı için" (Ersoy ve Saban, 2019, s. 83) nitel araştırma yöntemlerinden "Fenomonoloji (olgubilimi)" deseni kullanıımıştır. Hem bir felsefi bakış hem de bir araştırma yaklaşımı olarak karşımıza çıkan Fenomonoloji (Ersoy ve Saban, 2019, s. 82) gerçekliği bireysel bakış ve deneyimlerde arayan bir akım olarak gelişmiştir. Fenomonolojik araştırma, insan olgusu üzerine odaklanan, yaşanmış deneyimlerin ifade edilişinin anlamlarını tanımlamayı amaçlayan tümevarımsal betimleyici bir araştırmadır. İlk elden öznel bir bakış açısıyla olgunun çalışılmasını hedefler (Akturan ve Esen, 2008). Erken çocukluk dönemi peygamber düşüncesini incelemeyi amaçlayan bu araştırma, konuyla ilgili literatürün taranması, görüşme sorularının oluşturulması, görüşmenin gerçekleştirilmesi ve verilerin değerlendirilmesi biçiminde yürütülmüştür. Araştırmada betimleyici fenomonoloji yaklaşımı benimsenmiştir. Betimleyici fenomonoloji, epistemolojik bir bakış açısına sahiptir ve bireylerin bildikleri şeyin ne olduğu ile ilgilenir. Temel amaç insanların algı ve deneyimlerini betimlemektir (Ersoy ve Saban, 2019, s. 88). Eğitimle ilgili olması nedeniyle fenomonolojik eğitim araştırması olarak tanımlanabilecek bu çalışmada asıl amaç eğitimöğretim sürecinde yaşanan deneyimleri tanımlayarak anlayabilmek ve öğrenme -öğretme sürecini geliştirmektir. Bu açıdan temel amaç çalışmada çocukların peygamber ile ilgili düşüncelerini ortaya çıkartarak peygamberlerin erken çocukluk döneminde nasıl anlatılması gerektiğiyle ilgili pedagojik ilkelere ulaşmaktır.

\subsection{Katılımcılar}

Fenomenolojik araştırmalarda katılımcıları nasıl seçeceğimiz -araştırma fenomenine göre değişiklik gösterse de- birçok sebep dolayısıyla kimi zaman kolay kimi zaman zor bir süreç olabilme potansiyelindedir. Göz önüne alınması gereken en temel unsur araştırmaya katılan katılımcıların fenomene ilişkin deneyimlerinin olması ve araştırma sürecine katılmaya istekli olmalarıdır (Ersoy ve Saban, 2019, s. 108). Bu araştırmada katılımcılar "49 Yaş Yaz Kuran Kursu'na" devam eden öğrencilerden oluşmaktadır. Araştırmada, amaçı örnekleme yöntemlerinden kolay ulaşılabilir durum örneklemesi (convenience sampling) 
yöntemi kullanılmıştır. Çocuklar gönüllülük esasına göre araştırmaya katılmışlar ve ailelerinden de gerekli izin alınmıştır. Çocuklarla ön çalışma olarak nitelendirilen birtakım etkinlikler gerçekleştirilerek araştırmaya gönüllü olarak katılmaları sağlanmıştır. Araştırmacı üç gün boyunca çocuklarla tanışma başta olmak üzere farklı etkinlilere birlikte katılma, ihtiyaç duymaları halinde yardım etme, etkinlik aralarında birlikte oyun oynama gibi çeşitli faaliyetlerde çocukları gözlemlemiştir. Araştırmacı ve çocuklar arasında güvene dayalı bir ortam oluştuktan sonra araştırma başlatılmıştır.

Fenomenolojik çalışmalarda katılımcı seçimi kadar katılımcı sayısı da önemli bir karardır. Elbette ki çalışılan konuya/fenomene bağı olarak katılımcı sayısı değişecektir. Vagle fenomenolojik araştırmalarda katılımcı büyüklüğü konusunda sihirli bir sayı olmadığını söylemektedir (Ersoy ve Saban, 2019, s. 110). Genel olarak 5-25 kişi arasında olması gerektiği söylenirken en az 10 kişi olması gerektiğinden söz edilir ve genel kanı katılımcı sayısının az olmasından yanadır (Ersoy ve Saban, 2019, s. 110). Bu çalışma 11 çocuk ile gerçekleştirilmiştir. Araştırmaya katılan çocukların doğum tarihleri ve cinsiyetlerine ait bilgiler Tablo.1'de verilmişti.

Tablo 1. Araştırmaya Katılan Çocukların doğum tarihleri

\begin{tabular}{ccc}
\hline Katılımcı & Cinisyet & Doğum Tarihleri \\
\hline k-1 & Kız & 2017 \\
\hline K-2 & Kız & 2016 \\
\hline K-3 & Erkek & 2016 \\
\hline K-4 & Erkek & 2016 \\
\hline K-5 & Erkek & 2016 \\
\hline K-6 & Erkek & 2015 \\
\hline K-7 & Erkek & 2015 \\
\hline K-8 & Erkek & 2015 \\
\hline K-9 & Erkek & 2015 \\
\hline K-10 & Kız & 2014 \\
\hline K-11 & Kız & 2014 \\
\hline & & \\
\hline
\end{tabular}

\subsection{Veri Toplama}

Fenomenolojik araştırmalarda, veri toplama süreci fenomenin niteliği ve katılımcıların kişisel özellikleri doğrultusunda şekillenmektedir. Burada en temel ihtiyaç, katılımcıların fenomen ile ilgili algı, düşünce ve deneyimlerine daha iyi nasıl ulaşabileceği düşünülerek veri toplama sürecini ona göre planlayabilmektir. Görüşme, fenomenolojik araştırmalarda temel veri toplama tekniği olarak kabul edilir ve aynı katılımcı ile birden çok görüşme 
(çoklu görüşme) yapılması temel alınır (Ersoy ve Saban, 2019, s. 111). Fenomene ilişkin katılımcıların deneyimlerinin zengin bir biçimde ortaya konulabilmesi etkin bir görüşme sürecinin gerçekleştirilmesine bağlıdır. Fenomenolojik araştırmalarda görüşme, etkileşim ve iletişim süreci olarak görüldüğünden araştırmacı ve katılımcının sürece etkin katılımını gerekli kıldığı için diğer nitel araştırmalardan bazı yönleri ile ayrılır. Fenomenolojik görüşmede, sürecin dinamik yapısı ve araştırmacının ön deneyimleri görüşme sürecinin verimli geçmesi açısından oldukça önemlidir. Öncelikle görüşmenin doğası her ne kadar önceden araştırmacı tarafından hazırlanan sorular bağlamında ilerlemesi istense de katılımcılar ilgilerine göre süreci yönlendirebilirler. Bu ilk bakışta istenmeyen bir durum gibi görünse de aslında katılımcıların fenomen ile ilgili bakış açılarını yansıtması açısından çok değerli olabilir ve bize hiç hesap etmediğimiz detaylar, bilgiler verebilir (Ersoy ve Saban, 2019, s. 112). Böylesine dinamik olan görüşme sürecinin verimli bir şekilde yürütülebilmesi için araştırmacının ön deneyim sahibi olması da ayrıca büyük önem taşımaktadır.

Bu araştırmada erken çocukluk dönemindeki 4-6 yaşındaki çocukların peygamber ile ilgili algı, düşünce ve tasavvurları derinlemesine anlaşılmaya çalışıldığı için görüşme süreci özel olarak yapılandırılmıştır. Çalışmanın ilk günü çocuklarla tanışılııs ve çocuklar doğal ortamlarında gözlemlenmiştir. Farklı üç gün boyunca ${ }^{3}$ araştırmacı çeşitli etkinliklere katılarak çocuklarla vakit geçirmiştir. Çocuklar araştırmacıya alıştıktan sonra görüşmeler gerçekleştirilmiştir. Üç gün boyunca yapılan ön çalışmalarda büyük yaş grubundaki çocukların birçok etkinlikte küçük çocukları etkiledikleri fark edilmiştir. Özellikle sorulan sorulara, küçük gruptaki çocukların düşünmeden, büyük gruptaki çocukların verdikleri cevapları aynen tekrar ettikleri gözlemlenmiştir. Peygamber ile ilgili düşüncelerine ulaşmak için derinlemesine sohbetlerin gerçekleştirilebilmesi amacıyla 4, 5 ve 6 yaş grubu çocuklarla görüşmeler ayrı ayrı gerçekleştirilmiştir. Çocukların gelişim özelliklerinden dolayı görüşmeler bireysel ya da kalabalık gruplar halinde yapılmamıştır. Aynı yaşta olan çocuklarla 3-5 kişilik gruplar halinde 3 farklı oturumda görüşmeler yapılmıştır.

Araştırma öncesi grup öğretmeni çocukların ailelerine bilgi verdiği ve onay formlarını doldurmalarını sağladığı için görüşmeler ses kayıt cihazıyla kayıt altına alınmıştır. Ses kayıtları nasıl bir duygu içinde çocukların ne söylediklerini yeniden dinlemeye imkân verdiği ve doğrudan alıntı yapmaya müsait olduğu için kullanılmıştır.

Görüşme sırasında grup öğretmenleri de bulunmuş ve gerekli yerlerde araştırmacıya destek sağlayacak açıklamalar yapmıştır. Her oturumda sohbet "Buraya niçin geliyorsun?" sorusu ile başlatılmış ve devamında aşağıdaki sorular sorulmuştur.

"Allah’a karşı ne hissediyorsunuz?"

3 Çocukların araştırmacı ile etkili bir iletişime geçmeleri ve güvene dayalı bir ortamın oluşması için üç gün serbest çalışma yapılmıştır. 
Türkiye Din Eğitimi Araştırmaları Dergisi

Turkish Journal of Religious Education Studies

"Allah'ı niçin seviyorsunuz?"

“Peygamber ne demek? Biliyor musunuz?"

“Hiç peygamber gördünüz mü? Nerede?"

“Hangi Peygamberleri tanıyorsunuz? İsimlerini söyleyebilir misiniz?"

“Bildiğiniz peygamberleri size kim anlattı? Nereden öğrendiniz?”

Çocukların cevapları tek tek dinlenerek ne anlatmak istedikleri anlaşılmaya çalışıımıştır. Ayrıca çocukların birbirlerinin cevapları ile ilgili konuşmaları da desteklenmiştir. Uzun bir oyun arası verildikten sonra görüşmenin ikinci aşamasına geçilmiştir. Çocuklara "Peygamber/ler ile ilgili resim yapmak ister misiniz?" sorusu sorulmuştur. Çocukların hepsi resim yapmayı kabul etmişlerdir. Resimlerde anlatmak istedikleriyle ilgili ek açıklamalar çalışmalarının arka tarafına not edilmiştir.

Erken çocukluk döneminde çocuklar, kişiler arası ilişkiler yoluyla öğrenirler ve öğrenme ortamının duygusal iklimi oldukça önemlidir (Lee, 1988, ss. 168-169). Bundan dolayı araştırmacı çocuklarla araştırma sürecini uzun tutmuştur. Çocukların kendisine alışmasını sağladıktan sonra çocuklarla grup görüşmesi gerçekleştirilmiştir. Görüşmeler sohbet havasında çocukların kendilerini ifade etmeleri sağlanmıştır. Küçük yaş grubu ile çalışma deneyimi olan araştırmacı görüşme sürecini oldukça etkin bir şekilde yönetmeye ve çocukların peygamber ile ilgili ne düşündüklerini anlamaya odaklanmıştır. Her ne kadar çocukların düşüncelerinin dağınık ve dikkat sürelerinin kısa olması sohbetin aynı konu etrafına ilerlemesini zorlaştırsa da araştırmacı konuyu aynı yere getirerek sormak istediği soruları çocuklara yöneltebilmiştir. Çocukların özellikle konu ile ilgisiz gibi görünen konuşmaları araştırmacı tarafından detaylandırılarak anlaşılmaya çalışılmıştır.

Fenomenolojik araştırmalarda en temel veri toplama aracı görüşme olsa da yazılı materyaller, gözlem, görsel araçlar gibi birçok farklı veri toplama tekniğinden yararlanılabilir (Ersoy ve Saban, 2019, s. 111). Bu araştırmada çocuklarla gerçekleştirilen görüşmelerin yanında onlara peygamber/ler ile ilgili resimler de yaptırılmıştır. Çünkü çocukların yaptıkları resimler, onların yaşam deneyimlerini dolayısıyla iç dünyalarını ifade eden veri kaynakları olarak alanyazında değerlendirilmektedir (Leitch, 2008). Özellikle çocukların yaptıkları resimler ile ilgili geliştirilecek sohbet onların kendilerini daha fazla ifade etmelerine imkân verecekti. Ayrıca konuşmayı sevmeyen çocuklar açısından düşünce ve duygularını ifade etmeye fırsat tanıması yönüyle tercih edilmiştir. Bu amaçla çocuklara peygamber/lerle ilgili resim yapmak isteyip istemedikleri sorulmuştur. Bu fikre 5 ve 6 yaş grubu sıcak bakarken, 4 yaş grubu istememiştir. Ama diğer gruplardaki çocukların yaptıkları resimleri görmeleri üzerine yapmak istemişlerdir. 


\subsection{Verilerin Analizi}

Fenomenolojik yaklaşım veri analizini de kendi doğasına göre şekillendirmektedir. Alan yazında farklı veri analiz teknikleri olsa da genel olarak bu tekniklerin esnek ve karmaşık bir nitelik taşıdığı söylenebilir. Betimleyici fenomonolojide veri analizi genellikle deneyimlerin temalandırılarak betimlenmesi üzerine kurgulanır ve araştırmacı veri analiz sürecinde daha esnek davranabilmektedir (Ersoy ve Saban, 2019). Bu araştırmada görüşme sırasında alınan kayıtlar ve raporlar birlikte değerlendirilerek görüşmelerin dökümü yapılmıştır. Ses kayıtlarının yazıya dökülmesi aşamasında herhangi bir program kullanılmamış, ses kayıtları dinlenerek yazıya aktarılmıştır. İlk aşamada her yaş grubunun verileri önce kendi içerisinde değerlendirilerek önemli ifadeler belirlenmiştir. Daha sonra her yaş grubunda ortaya çıkan ortak ifadeler tespit edilmiştir. Son aşamada ise ortak ifadeler yaşlara göre değerlendirilerek Allah, Kuran, dua ve peygamber ile ilgili çocukların düşünceleri betimlenmiştir.

Resimlerinden elde edilecek veriler, çocukların çizimlerini yarıda bırakmalarından dolayı değerlendirilememiştir. Çocuklar istedikleri şeyi çizememekten kaynaklanan bir korku yaşamışlar ve bu yüzden resim yapmak istememişlerdir. Çocuklara güzel çizmenin ötesinde önemli olanın duygularını, düşüncelerini ifade etmek olduğu açıklanmış ve çalışmalarına devam etmeleri için teşvik edilmişlerdir. Ama çocukların bir kaçında yaşanan bu kararsızlık ve isteksizlik diğer çocukları da etkilemiştir. Bunun sonucunda resim yapma sürecinde çocukların dikkatleri dağılmış ve kendi aralarında oyun oynamaya başlamışlardır. Resimlerini tamamlamaları için yapılan hatırlatmalarda da resim yapmak istemediklerini, oyun oynamak istediklerini söylemişlerdir.

\subsection{Araştırmacının Rolü}

Doğaları gereği sayılarla anlam bulan nicel araştırmalarda veriler istatistiksel işleme tabi tutulduğu için araştırmacının rolü bağımsız bir gözlemci iken, kelimelerle anlam bulan nitel araştırmalarda araştırmacı doğal olarak araştırma yaptığı olgu ile iç içedir (Fraenkel and Wallen and Hyun, 2012). Verilerin toplanması ve analiz işlemlerinde nitel paradigmalarda araştırmacı doğrudan sürecin içerisindedir. Bu yönüyle araştırmacı da bir veri toplama aracıdır (Patton, 2002). Bu bağlamda küçük yaş grubu çocuklarla uzun yıllar farklı disiplinlerde (astronomi, arkeoloji, yaratıcı yazarlık gibi) çalışma deneyimim bulunmaktadır. Uzmanlık alanımın gereği olarak çocukların gelişimlerini gözlemleme ve nasıl öğrendiklerini anlama ile ilgili çalışmalar yapmaktayım. Farklı öğrenme disiplinlerini çocuğun gelişim özelliklerine göre nasıl öğretilmesi gerektiği ile ilgili müfredat/içerik hazırlama sırasında çocukların gelişimlerinin niteliğini ve hızlarını anlamanın önemini fark ettim. Çocuğun gelişimi kompleks ve çok boyutlu bir nitelik taşmaktadır. Özellikle dini gelişim alanındaki ilerlemenin diğer gelişim alanları ile oldukça sıkı bir ilişkisi vardır. Dini içeriklerde çocuğun gelişim alanlarının özelliklerinin dikkate alınması gerektiğine inanıyorum. Çocuklarla gerçekleştirdiğim birçok etkinlikte dini içeriğin çocuğun gelişim 
özelliklerine göre verilmediğinde istenen hedefe ulaşıımadığını gözlemledim. Dini içeriğin çocuğa nasıl anlatılması gerektiği ile ilgili çalışmalarımda da çocukların ne düşündükleri ve nasıl öğrendikleri ile ilgili çalışmaların yol gösterici niteliğinin yetersiz olduğunu fark ettim. Bu düşüncelerden hareketle küçük yaş grubuna dini içeriğe ait önemli bir konu olan peygamber/lerin nasıl anlatılabileceği ile ilgili bir çalışma yapmak istedim. Çocukların gelişim yeterlilikleri çalışmanın çıkış noktası olması gerektiğini düşündüğüm için onların peygamber ile ilgili ne düşündüklerini anlamak istedim. Çocuklarla birlikte vakit geçirdikçe seçtiğim konunun ne kadar önemli olduğunu fark ettim. Özellikle görüşmelerden elde edilen verilerin analiz etme aşamasında çocukların dini düşüncelerindeki benzerlik onların gelişim hızlarını ve niteliğini anlamam konusundaki fikirlerimi netleştirdi. Peygamberlerin nasıl anlatılması gerektiği ile bu süreç benim açımdan oldukça heyecan verici ve keyifliydi.

\section{Bulgular ve Yorumlar}

Fenomenolojik araştırmalarda verilerin nasıl yazılacağı ile ilgili alanda farklı yaklaşımlar vardır. Verilerin yazıya dökülmesi ve sunumu birey ya da durum temelli yapılabilir (Yıldırım ve Şimşek, 2006). Az katılımcı ile çalışılan bir araştırmada birey temelli bir yaklaşım benimsenerek her katılımcının tüm görüşleri sunulabilir. Katılımcı sayısının çok olduğu durumlarda sunum temelli bir yaklaşım içerisinde katılımcıların görüşleri temalar bağlamında açıklanabilir. Yazım biçimlerine ilişkin bu kararı araştırmacı kendisine "Verileri okuyucu için nasıl daha iyi sunulabilir?" sorusunu düşünerek vermelidir (Ersoy ve Saban, 2019, s. 123). Bu araştırmada katılımcı sayısının az ve küçük yaş grubu çocuklarının doğaları gereği diyaloglarının kısa olması nedeniyle her yaş grubunda gerçekleştirilen görüşmelerin tamamına yer verilmiştir.

\subsection{Yaş Grubu Çocuklarla Gerçekleştirilen Görüşme Bulguları ve Yorumlar}

Tablo. 2'de 4 yaş grubu görüşmesine katılan çocukların listesi verilmiştir. Görüşme süresi yaklaşık 22 dakika sürmüştür. Çocukların gerçek isimleri yerine müstear isimler kullanılmıştır.

Tablo.2 Görüşme yapılan 4 yaş grubu çocukların listesi

\begin{tabular}{lcc}
\hline Katılımcı & Cinsiyet & Doğum Yılı \\
\hline Sümeyye & Kız & 2017 \\
\hline Ayşem & Kız & 2016 \\
\hline Mehmet Ali & Erkek & 2016 \\
\hline Hacı & Erkek & 2016 \\
\hline Ömer Faruk & Erkek & 2016 \\
\hline Onur Efe & Erkek & 2016 \\
\hline
\end{tabular}

Görüşme, çocukların nasıl oldukları ve o gün neler yaptıkları ile ilgili sorularla araştırmacı tarafından başlatılmıştır. 
Araştırmacı: Bir şey soracağım! Siz buraya niçin geliyorsunuz? Niye buradasınız? Niye evde değilsiniz?

Ayşem: Öğrenmek için, Allah için buraya geliyorum.

Araştırmacı: Öğrenmek için, Allah için geliyorsun. Anladım! Peki, bunu tek tek sorsam? Onur Efe sen niçin buraya geliyorsun?

Onur Efe: Öğrenmek için, Allah için geliyorum.

Araştırmacı: Sümeyye sen?

Sümeyye: Allah için geliyorum, öğrenmek için.

Araştırmacı: Sümeyye buraya gelince Allah için bir şey mi yaptığını düşünüyorsun?

Sümeyye: ...(Bilmiyorum anlamında kafasını sağa sola sallamıştır.)

Ayşem: Biz boyama yapıcaz. Ben şimdi dışına çıkarmayacağım.

Araştırmacı: Peki niye buraya geliyorsun Mehmet Ali?

Mehmet Ali: Öğrenmek için geliyorum.

Araştırmacı: Neyi öğrenmek için geliyorsun Mehmet Ali? Matematik? Hayat bilgisi, toplama çıkarma mı?

Mehmet Ali: Kuran öğrenmek için geliyorum.

Araştırmacı: Hacı sen niye geliyorsun?

Hacl: Öğretmeni görmeye geliyorum. Seni görmeye geliyorum

Araştırmacı: Çok teşekkür ederim Hacı! Anladım buraya Kuran için geliyorsunuz! Peki, Kuran ne demek?

Ayşem: Dua demek

Araştırmacı: Çok teşekkürler Ayşem! Sümeyye sence Kuran ne demek?

Sümeyye: Dua.

Araştırmacı: Mehmet Ali sence Kuran ne demek?

M. Ali: Çalışmak.

Araştırmacı: Anladım! Onur Efe? Sen ne diyorsun? Kuran ne demek?

Onur Efe: Allah demek.

Hacı: Kuran demek Allah demek!

Araştırmacı: Peki, dua ne demek?

Sümeyye: Allah demek. 
Ayşem: Allah demek

Araştırmacı: Allah deyince ne oluyor Ayşem?

Ayşem: Amin.

Araştırmacı: Sümeyye sence ne oluyor Allah deyince?

Sümeyye: Amin.

Araştırmacı: Amin ne demek?

Onur Efe: Dua demek

Araştırmacı: Hacı sence dua demek ne demek?

Hacl: Allah.

Araştırmacı: Şimdi bir şey daha soracağım? Ama bu çok özel bir soru?

Ayşem: Bir şey diyeceğim!

Araştırmacı: Evet Ayşem!

Ayşem: Ne zaman dondurma yiyeceğiz?

Araştırmacı: Hava çok sıcak olduğu için dondurma getiremedim. Çünkü burada dolap yokmuş. Ama size farklı farklı şeyler getirdim. Onları yiyeceğiz. Parti yapacağız sizleler...

Çocuklar hep birlikte: Yaşasın...

Ayşem: Bir şey diyeceğim. Benim okulda büyüdüğüm zaman doğum günüm olacak!

Araştırmacı: Ay çok güzel!

Ayşem: Sen de gel doğum günüme!

Araştırmacı: Yaa... Çok teşekkür ederim Ayşem! Çok gelmek isterim!

Onur Efe: Benim doğum günüm geçti! Geçtiği zaman 5 yaşına geçiyorum.

Araştırmacı: Geçti mi? Ama her yıl bir tane doğum günün olacak!

Hacı: Ben... Ben... Bu kadar doğum günüm kaldı. Abimin de bu kadar! (Elleriyle beş ve on yaptı.)

Ayşem: Benim dayım da otuz yaşında

Katılımcl: Ooo.

Onur Efe: Benim abim atmış iki yaşında...

Katılımcı: Ooo... Aman Allah’ım!

Mehmet Ali: Ben beş yaşındaydım. Altı yaşıma girdim. 
Katılımcı: Maşallah size! Şimdi bir soru soracağım. Şöyle yaklaşın bakalım! Yaklaşın! Açın kulaklarınız! "Allah'ı seviyor musunuz?"

Çocuklar (coşkuyla): Eveeet!

Araştırmacı: Emin misiniz?

Çocuklar: Eveeet!

Araştırmacı: Niye seviyorsunuz peki Allah'ı?

Hacl: Seviyoruz!

Ayşem: Ben çok seviyorum Allah'ı!

Onur Efe: Allah bizi yarattı.

Araştırmacı: Allah bizi yarattı diyor Onur Efe!

Ayşem: Evet! Allah bizi yarattı.

Araştırmacı: Onun için mi çok seviyorsunuz?

Hacl: Hasta oldum!

Araştırmacı: Şimdi mi hasta oldun?

Ayşem: Ben de hasta oldum, iyileştim.

Sümeyye: Ben de hasta oldum, iyileştim.

Burada konuşma dağıldı.

Araştırmacı: Peki bir şey söyleyeceğim! Allah'ı çok seviyorsunuz bunu anladım! Ben de Allah'ı çok seviyorum. Etrafınızda Allah'ı sevmeyen var mı peki?

Ayşem: Görmedim ben!

Onur Efe: Hırsızlar!

Araştırmacı: Hırsızlar mı? HıIı... Anladım! İyi bir şey yapmadıkları için Allah'ı sevmediklerini mi düşünüyorsun?

Onur Efe:... (Evet anlamında kafasını salladı.)

Ayşem: Bir şey diyeceğim! Bizim evde hırsız vardı. Polisler yakaladı onu. Hapishaneye koydular! Araştırmacı: Aa... Hadi polisleri bir alkışlayalım!

Alkışşş...

Hacı: Bir şey diyeceğim! Annemin de dedesi yanımıza geldi...

Ayşem: Bizim mezar yandı. Sonra köy yandı.

Araştırmacı: Ama ben çok üzüldüm şimdi! 
Ayşem: Bir şey diyeceğim. Bizim orası haberlerde çıkıyor.

Hacı: Ateşle, kibritle ve çakmakla oynamak çok tehlikeli.

Onur Efe: Benim annem hastaydı karantinadaydı...

Araştırmacı: Çok geçmiş olsun!

Araştırmacı: Allah deyince aklınıza ne geliyor? Neler geliyor?

Çocukların dikkatlerinin dağılması üzerine soru oyunlaştırılmıştır.

Araştırmacı: Hadi bunu oyun gibi yapalım! Gelip kulağıma söylemek ister misiniz? Hacı koş gel hadi!

Hacı koşarak gelir.

Araştırmacı: Hacı seni dinliyorum! Allah deyince aklına ne geliyor?

Hacı: Benim dedem öldü.

Araştırmacı: Anladım Hacı! ... Sen koş gel Sümeyye! Sümeyye Allah deyince aklına ne geliyor? Sümeyye: Bilmiyorum...

Araştırmacı: Sen biraz daha düşün o zaman! Hadi sıra sende Onu Efe! Senin aklına ne geliyor? Onur Efe: Hızlı motor!

Araştırmacı: Aa... Hızlı motor mu? Neden aklına motor geldi?

Onur Efe: Çünkü Allah'tan onu istiyorum.

Araştırmacı: Anladım! Sıra sende Ayşem! Ayşem koş!

Ayşem: Dua geliyor aklıma.

Araştırmacı: Mehmet Ali senin aklına ne geliyor Allah dediğimiz zaman?

Mehmet Ali: Aklıma bir şey gelmiyor.

Araştırmacı: Sümeyye aklına bir şey geldi mi?

Sümeyye: Aklıma bir şey gelmedi.

Kendi aralarında tekrar konuşmaya başladılar. Çocukların ilgilerini tekrar toplamak için müzik eşliğinde dans edildi. Sonrasında görüşmeye devam edildi.

Araştırmacı: Peygamber ne demek? Kimler duydu peygamberi?

Mehmet Ali: Ben duymadım!

Ayşem: Ben de duymadım!

Onur Efe: Ben de duymadım! 
Hacl: Ama ben Allah'ın adını biliyorum.

Araştırmacı: Peygamberi kimler duydu bir el kaldırsın?

Sadece iki kişi el kaldırdı.

Araştırmacı: Sizler duymadınız mı? Peki, peygamber ne demek?

Hacı: Allah demek! Allah demek!

Araştırmacı: Peygamber ne demek?

Çocuklar (toplu olarak): Allah demek!

Araştırmacı: Mehmet Ali sence peygamber demek ne demek?

Onur Efe: Allah demek!

Araştırmacı: Hacı sen de mi aynı şeyi düşünüyorsun?

Hacl: Evet!

Araştırmacı: Hiç peygamber gördünüz mü?

Onur Efe: Peygamberin yanına gidicem.

Araştırmacı: Peki niye gideceksin?

Onur Efe: Ben gidicem!

Araştırmacı: Onları görüp geri mi geleceksin? Sence nerede peygamberler?

Mehmet Ali: Örümcek adam...

Onur Efe: Örümcek adam değil! Çok uzakta. Ankara'da, İstanbul'da.

Araştırmacı: Oraya ancak örümcek adam olarak mı gidilebilir diyorsun! Çok uzakta yani...

Ayşem: Tek başına gitme kaybolursun.

Onur Efe: Ben abimle gidicem.

Araştırmacı: Hangi peygamberi tanıyorsunuz? Hiç bildiğin bir peygamber adı var mı?

Sümeyye: Namaz kılarken söylüyoruz.

Araştırmacı: Aaa... Ben anladım. Namaz kılarken söylüyoruz. Ama ben kim olduğunu söylemeyeceğim. Hacı bildiğin peygamber var mı?

Hacl: Allah'ımız var. Allah'ın bir ismi Hazreti Muhammed.

Onur Efe: Ben bir şey söyleyeceğim!

Araştırmacı: Bir dakika Onur Efe! Ayşem senin bildiğin bir peygamber var mı?

Ayşem: Var! 


\section{Araştırmacı: Kim?}

Ayşem: Bilmiyorum ama babamın bir ismi Muhammed.

Onur Efe: Ben de söyleyeceğim ben de!

Araştırmacı: Evet Onur Efe!

Onur Efe: Allah peygamberimizi döver.

Araştırmacı: Hı... Öyle mi? Peki, hiç bildiğin bir peygamber var mı?

Onu Efe: Var!

Araştırmacı: Kim?

Onur Efe: Allah!

Araştırmacı: Mehmet Ali senin bildiğin peygamber isimleri var mı?

Mehmet Ali: Yok!

Araştırmacı: Sümeyye senin? Aa... Sen söylemiştin!

Ayşem: Bir şey söyleyeceğim!

Araştırmacı: Evet Ayşem!

Ayşem: Biz gelirken deli kadın geldi ama sola döndü.

Araştırmacı: Anladım! Şimdi ara zamanı! Hepinize çook çok teşekkür ediyorum!

Ayşem: Hadi parti yapalım!

Onur Efe: Parti! Parti!

Görüşme burada sonlandırılmıştır.

4 yaş grubu çocukları "Niye buraya geliyorsun?" sorusuna "Öğrenmek, Allah ve Kur'an” cevabını vermişlerdir. Çocuklara devamında neyi öğrenmek için geldikleri sorusu sorulduğunda "Kur'an" cevabını vermişlerdir. "Kur'an nedir?" sorusuna ise "dua, çalışmak, Allah" cevabını vermişlerdir. "Dua ne demektir?" sorusuna "Allah" cevabını vermişlerdir. Çocukların hepsi Allah'ı çok sevdiklerini ifade etmişleridir. "Allah’ı neden seviyorsunuz?" sorusuna "Bizi O yarattı." cevabını vermişlerdir. "Allah deyince aklınıza ne geliyor?" sorusuna ise "dedem öldü, hızlı motor ve dua" cevapları verilmiştir. "Peygamber ne demek? Peygamber kimdir?" sorusuna ise yine "Allah" cevabı verilmiştir.

4 yaşındaki çocukların Kur'an, dua ve peygamber kavramları ile ilgili net bir fikirlerinin olmadığı, bu kavramları Allah ile ilişkilendirdikleri görülmüştür. Ölen dedesi ya da çok istediği hızlı motor için dua etmesi cevaplarından anlaşılacağı üzere çocuklarda Allah kavramı dua kavramı ile ilişkilendirilmiştir. 


\subsection{Yaş Grubu Çocuklarla Gerçekleştirilen Görüşme Bulguları ve Yorumları}

Tablo. 3'de 5 yaş grubu görüşmesine katılan çocukların listesi verilmiştir. Görüşme süresi yaklaşık 16 dakika sürmüştür. Çocukların gerçek isimleri yerine müstear isimler kullanılmıştır.

Tablo 3. Görüşme yapılan 5 yaş grubu çocuklar listesi

\begin{tabular}{lcc}
\hline Katılımcı & Cinsiyet & Doğum Yılı \\
\hline Yiğit & Erkek & 2015 \\
\hline Murtaza & Erkek & 2015 \\
\hline Bekir & Erkek & 2015 \\
\hline Ahmet & Erkek & 2015 \\
\hline
\end{tabular}

Görüşme, çocukların nasıl oldukları ve o gün neler yaptıkları ile ilgili sorularla araştırmacı tarafından başlatılmıştır.

$\cdots$

Araştırmacı: Niye buraya geliyorsunuz?

Murtaza: Kur'an okumak ve öğrenmek için geliyoruz.

Araştırmacl: Ahmet sen niye geliyorsun?

Ahmet: Geçmek için... Kur'an'a geçmek için

Araştırmacı: Yiğit! Yiğit sen niye geliyorsun buraya?

Yiğit: Kur’an öğrenmek için.

Araştırmacı: Bekir sen niye geliyorsun buraya?

Bekir: Aklımızı çalıştırmak için ve önemli bir şey yapmak için. Çünkü Kur’an çok güzel bir şey.

Araştırmacı: Peki Kur'an ne demek Bekir sence?

Bekir: Kur'an... Kur'an öğreniyoruz...

Araştırmacı: Anladım! Peki, Kur'an ne demek?

Bekir: Kur'an ne demek? Kur'an'ı Allah yaratmıştır.

Araştırmacı: Peki herkese soruyorum! Kur'an ne demek arkadaşlar?

Yiğit: Kur’an Allah demek!

Araştırmacı: Bir düşünün arkadaşlar! Kur’an ne demek?

Bekir: Kur'an nedir? Çünkü Allah onu yarattığı için Kur'an'ların hepsini... Kur'anı Allah yarattığı için Kur'anların hepsini o yüzden Allah'ın bu okulu da yaratması lazımdı. Allah bu okulu yarattığı için Kur'an'ları da yarattı.

Araştırmacı: ... Ahmet sence Kur'an ne demek? 
Ahmet: Dua demek olabilir mi?

Araştırmacı: Peki Ahmet dua demek ne demek?

Bekir: Dua ne demek...

Araştırmacı: Ahmet cümlesini bitirsin sonra sen devam et. Ahmet sence dua ne demek?

Ahmet: Kur'an'a benzeyen... Kur'an'a benzeyen bir şeydir.

Araştırmacı: Anladım! Dua Kur'an’a benzeyen bir şeydir diyorsun! Peki, iyi bir şey mi kötü bir şey mi?

Ahmet: İyi!

Araştırmacı: İyi bir şey! HıII... Murtaza sence Kur’an ne demek?

Murtaza: Allah demek!

Araştırmacı: Allah demek! Hım... Anladım! Peki, hiç dua ediyor musunuz?

Çocuklar (toplu şekilde): Evet...

Araştırmacı: Ediyorsunuz! Neyle ilgili dua ediyorsunuz? Ve kime ediyorsunuz? Dua kime edilir?

Ahmet: Ben hacı dedeme ediyorum.

Araştırmacı: Sen hacı dedeme ediyorum diyorsun! Anladım! Bekir?

Bekir: Ben anneme babama dua ediyorum. Neneme ediyorum...

Araştırmacı: Yiğit sen kime ediyorsun?

Yiğit: Kardeşime dua ediyorum.

Araştırmacı: Kardeşine ne için dua ediyorsun?

Yiğit: Ben “Ettehiyyatü” okuyorum.

Araştırmacı: Ettehiyyatü okuyorsun?

Yiğit: Evet! Çünkü öğrensin diye.

Araştırmacı: Ona öğrensin diye "ettehiyyatü" duasını okuyorsun! Hımm...

Bekir: Ettehiyyatü duasını okuyayım mı?

Yiğit: Ayın kaçı biliyor musun? Kaçta doğdu o? O... O... on iki ay 2021. Tarihi şey? Tarihi 16.

Araştırmacı: Murtaza? Sen hiç dua ediyor musun?

Murtaza: Ediyorum...

Araştırmacı: Sen ne için dua ediyorsun?

Murtaza: Babam için ediyorum. 
Atik, Erken Çocuklukta Peygamber Tasavvuru ve Din Eğitimi: Fenomenolojik Bir Araştırma

Araştırmacı: Niye?

Murtaza: Çünkü onu çok seviyorum.

Araştırmacı: Babalar sevilmez mi hiç? Değil mi? Peki! Niye dua ediyorsunuz? Bunu hiç düşündünüz mü?

Bekir: Neden çünkü... Babamızı Allah yarattı!

Ahmet: Evet! Allah yarattı!

Bekir: Allah yarattı! Annelerimizi Allah yarattı! Nenelerimizi Allah yarattı!

Yiğit: Nenelerimiz de mi?

Murtaza: Benim anneannemi de Allah yarattı!

Bekir: Dedelerimizi Allah yarattı! Hepsini Allah yarattı!

Araştırmacı: Ahmet?

Ahmet: Ben köye gideceğim.

Araştırmacı: O zaman bir şey diyeceğim! Allah ile aranız nasıl? Allah’a karşı ne hissediyorsunuz?

Bekir: Allah'a karşı ben dua ediyorum.

Araştırmacı: Yiğit sen Allah’a karşı ne hissediyorsun?

Yiğit: Ee... Yeni hissediyorum.

Araştırmacı: Yeni? Yeni hissediyorsun? Ha... Anladım! Buraya geldikten sonra mı yeni yeni bir şey hissetmeye başladın?

Yiğit: Evet!

Araştırmacı: Buraya geldikten sonra bir şeyler hissetmeye başladın. Ondan önce bir şey düşünmüyor muydun?

Bekir: ?

Yiğit: Yok.

Araştırmacı: Yok! Anladım! Peki Ahmet! Sen ne hissediyorsun?

Ahmet: Düşünmedim!

Araştırmacı: Hiç düşünmedin! Tamam! Murtaza sen ne düşünüyorsun?

Murtaza: Hım... Rabbena'yı...

Ahmet: Başka?

Murtaza: "Rabbi yessir" de diyorum.

Araştırmacı: Çok güzel! Bekir? 
Bekir: Neden biz maske takıyoruz. Çünkü koranadan dolayı. Çok bulaştığı için...

Burada sohbet kısa bir süre dağıldı.

Araştırmacı: Çok güzel! O zaman hepinize şunu sorayım! Allah'ı seviyor musunuz?

Yiğit: Evet!

Bekir: Evet!

Araştırmacı: Murtaza Allah'ı seviyor musunu?

Yiğit: Mesela şu Allah! (Atatürk'ü gösterdi.)

Araştırmacı: O Allah diyorsun?

Yiğit: Hı hı...

Araştırmacı: Peki hiç Allah'ı gördünüz mü?

Murtaza: Yooo...

Araştırmacı: Görmediniz! Görmek ister miydiniz?

Murtaza: Evet

Ahmet: Allah bizi görüyor!

Araştırmacı: Evet! O bizi görüyor! Bekir Allah’ı görmek ister miydiniz?

Bekir: Evet!

Sohbet dağıldı...

Araştırmacı: Diğer bir sorum geliyor! Yiğit! Yiğit!

Bekir: İlk benden başlasın!

Araştırmacı: Tamam senden başlasın! Hiç peygamber diye bir şey duydunuz mu? Peygamber ne demek?

Bekir: Ne demek peygamber? Onu? Peygamber neden oldu?

Araştırmacı: Sen biraz daha düşün peygamber ne demek diye! Yiğit? Peygamber ne demek sence?

Yiğit: Ben de bilmiyorum.

Araştırmacı: Ahmet sence ne demek?

Ahmet: Peygamber namaz kılmak demek!

Araştırmacl: Murtaza peygamber ne demek sence?

Murtaza: Allah demek! 
Atik, Erken Çocuklukta Peygamber Tasavvuru ve Din Eğitimi: Fenomenolojik Bir Araştırma

Araştırmacı: Peki hiç peygamber gördünüz mü hayatınızda?

Bekir: Ben gördüm. Çünkü ben haberlerde peygamberi görüyorum, duyuyorum

Araştırmacı: Peki nasıl görüyorsun? Duyuyorsun?

Bekir: Peygamber diyorlar! Allah diyorlar!

Araştırmacı: Haberlerde peygamber diyorlar! Allah diyorlar! Anladım Bekir! Peki, Ahmet sen hiç peygamber gördün mü?

Ahmet: Yok!

Araştırmacı: Yiğit sen?

Yiğit: Yok!

Araştırmacı: Anladım görmedin! Murtaza?

Murtaza: Ben görmedim.

Araştırmacı: Hiç peygamber ismi biliyor musun?

Yiğit: Ben bilmiyorum.

Araştırmacı: Ahmet sen?

Ahmet: Bilmiyorum.

Araştırmacı: Murtaza? Sen hiç peygamber ismi biliyor musun?

Murtaza: Allah!

Araştırmacı: Anladım! Allah dışında biliyor musun?

Murtaza: Yok.

Araştırmacı: Peygamberle ilgili sormak istediğiniz bir şey var mı?

Bekir: Ben!

Araştırmacı: Evet Bekir!

Bekir: III... Ben peygamberi... Peygamberi hayatımda hiç görmediğim için bir şey söyleme hakkım yok. Ama peygamberi duyduğumda hiçbir şey bilmiyorum.

Araştırmacı: Anladım! Peki, Allah ile ilgi sormak istediğiniz sorular var mı?

Murtaza: Allah'ı görmüyoruz.

Ahmet: Ama ben Allah'ı rüyamda görüyorum.

Araştırmacı: Peki nasıl görüyorsun rüyanda Allah’ı Ahmet?

Ahmet: Bulutların üzerinde görüyorum. 
Araştırmacı: Peki Ahmet? Allah ile ilgili bir soru var mı senin?

Ahmet: Rüyamda görüyorum.

Yiğit: Ben geçen gün teyzemgile gittik. Orada bir ev vardı. Hem de bulutların üstüne çıkmıştık rüyamda...

Araştırmacı: Anladım. Bu aklına geldi sanırım senin de aklına...

Yiğit: Evet!

Araştırmacı: Peki Bekir? Sen?

Bekir: Ben Allah'ı rüyamda görüyorum.

Araştırmacı: Peki nasıl görüyorsun?

Bekir: Allah bulutların üstünde ama ben Allah’ı görüyorum. Böyle her taraf ağaçlıktı. Ortasında ev vardı. Bahçeli ev. Biz içinde oturuyoruz. Ben Allah'ı yakından görüyorum...

Araştırmacı: Anladım. Başka soru sormak isteyen var mı?

Yiğit: Öğretmenim bu dağların üzerinden bulutlara kadar gidiyorum.

Ahmet: Allah Atatürk'ü yarattı.

Sohbet dağıldı...

5 yaş grubu "Niye buraya geliyorsun?" sorusuna "Kur'an okumak, öğrenmek ve Kur’an'a geçmek için" cevabını vermişlerdir. "Kur'an ne demek?" sorusuna "Kur'an'ı Allah yaratmıştır, dua ve Allah" cevabını vermişlerdir. "Peki, dua ne demektir?" sorusuna "Kur'an'a benzeyen ve iyi bir şeydir" cevabı vermiştir bir çocuk. Çocuklara ne/ler için dua ettikleri sorulduğunda "hacı dedeme, anneme, babama, neneme, kardeşime" cevabını vermişlerdir. Çocukların duayı sevdiği insanlar için iyi dilekte bulunma olarak anladıkları söylenebilir. Sadece bir çocuk kardeşine ettehüyatü öğrettiğini söylemiştir. Allah’a karşı ne hissediyorsunuz sorusuna "ben Allah'a dua ediyorum, buraya gelince bir şeyler hissetmeye başladım, düşünmedim, Rabbi yessir, Rabbena" cevapları verilmiştir. Bu yaş grubu çocuklar da Allah'ı çok sevdiklerini ifade etmişlerdir. Sohbet sırasında çocuklardan biri sınıfta bulunan Atatürk resmini göstererek "Bu Allah'tır!" demiştir. Tüm çocuklar Allah'ı hiç görmediklerini ve görmek istediklerini söylemiştir. Bu sırada bir çocuk "O bizi görüyor!" demiştir. "Hiç peygamber diye bir şey duydunuz mu? Peygamber ne demek?" sorusuna "bilmiyorum, namaz kılmak demek, Allah demek" cevaplarını vermişlerdir. "Peki, hiç peygamber gördünüz mü hayatınızda?" sorusuna bir çocuk haberlerde "peygamber, Allah" dediklerini duyduğunu söylemiştir. "Hiç peygamber ismi biliyor musunuz?" sorusuna "bilmiyorum, Allah" cevabı verilmiştir. Yine iki çocuk Allah'ı rüyalarında bulutların üzerinde gördüklerini anlatmıştır. Başka bir çocuk bu sırada "Atatürk'ü Allah yaratmıştır." demiştir. 5 yaşındaki çocukların Allah'ı, Kur'an ve Peygamber olarak 
düşünmelerinden dolayı Allah ile ilgili düşüncelerinin oldukça dağınık ve tutarlı olmadığı söylenebilir. Ayrıca sınıfta resmi bulunan Atatürk ile ilgili de çelişkili düşünceler yaşadıkları görülmüştür. Muhtemelen Allah'ı görememeleri gibi Atatürk'ü de göremediklerinden kaynaklanan bu durum çocuklarda bir takım yanlış anlaşılmalara neden olmaktadır. Soyut düşünme aşamasında olmayan bu dönem çocuklarında Allah'ın yaratmaları ve Atatürk'ün kahramanlıkları ile ilgili anlatımlar muhtemel yanlış ilişkilendirmelere sebep olmaktadır.

\subsection{Yaş Grubu Çocuklarla Gerçekleştirilen Görüşme Bulguları ve Yorumları}

Tablo. 4'de 6 yaş grubu görüşmesine katılan çocukların listesi verilmiştir. Görüşme süresi yaklaşık 6 dakikadır. Çocukların gerçek isimleri yerine müstear isimler kullanılmıştır.

Tablo 4. Görüşme yapılan 6 yaş grubu çocuklar listesi

\begin{tabular}{lcc}
\hline Katılımcı & Cinsiyet & Doğum Yılı \\
\hline Miray & Kız & 2014 \\
\hline Gamzenur & Kız & 2014 \\
\hline
\end{tabular}

Görüşme, çocukların nasıl oldukları ve o gün neler yaptıkları ile ilgili sorularla araştırmacı tarafından başlatılmıştır.

Araştırmacı: Buraya niçin geliyorsunuz?

Miray: Kur'an okumak için!

Araştırmacı: Gamze sen niye geliyorsun?

Gamzenur: Kur'an okumak için!

Araştırmacı: Kur'an ne demek peki?

Miray: Allah demek.

Araştırmacı: Kur'an Allah demek! Peki, Kur'an ne demek Gamze?

Gamze: Allah!

Araştırmacı: Allah demek! Allah ile aranız nasıl o zaman?

Miray: İyiiii...

Gamze: İyi...

Araştırmacı: Seviyor musunuz Allah'ı?

Miray: Evet!

Araştırmacı: Niye seviyorsunuz Allah'ı? Gamze Allah'ı niye seviyorsun?

Miray: Çünkü o bizim Allah'ımız! 
Araştırmacı: Ama sıra Gamze'de! Gamze cevaplayacak! Gamze Allah’ı niye seviyor musun? Gamze: ...

Araştırmacı: Sen söyler misin Miray? Allah'ı niye seviyorsunuz?

Miray: Çünkü o bizim Allah'ımız!

Araştırmacı: Peki ne yapıyor sana?

Miray: Bilmiyorum...

Araştırmacı: Anladım! Peki, Allah deyince aklınıza ne geliyor?

Gamze: ...

Miray: ...

Araştırmacı: Hiç peygamber duydunuz mu?

Miray: Hayır!

Araştırmacı: Peygamber ne demek? Biliyor musunu?

Gazme: Peygamber Allah demek!

Araştırmacı: Peygamber Allah demek. Anladım! Hiç peygamber ismi duydunuz mu?

Miray: Yooo...

Araştırmacl: Sen Gamze?

Gamze: Yoo...

Araştırmacl: Peki hiç peygamber gördünüz mü?

Miray: Yoo...

Araştırmacı: Sen Gamze?

Gamze: Görmedim!

Araştırmacı: Miray! Hiç peygamber adı biliyor musun?

Miray: Bilmiyorum

Araştırmacı: Allah ile ilgili soru sormak ister misiniz? Aklınıza takılan bir soru var mı?

Miray: Yok!

Gamze: Yok!

Araştırmacı: Anladım! Teşekkür ediyorum o zaman size... 
6 yaş grubu çocukları "Buraya niçin geliyorsunuz?" sorusuna "Kur’an okumak için" cevabını vermişlerdir. "Peki, Kur'an ne demektir?" sorusuna "Allah" cevabını vermişlerdir. Allah'ı sevdiklerini ve sevme nedenlerini de "Çünkü O bizim Allah'ımız " cevabını vermişleridir. "Peygamber ne demek? Biliyor musunuz?" sorusuna "Hayır” cevabını vermişlerdir. Bu yaş grubu çocukların düşüncelerinin 4 - 5 yaş grubuna göre dağınık olmadığı söylenebilir.

\subsection{4, 5 ve 6 Yaş Grubu Çocuklarının “Kur’an, Dua, Allah ve Peygamber” ile ilgili Karşılaştırmalı Bulguları ve Yorumları}

Kuran, dua, Allah ve peygamber ile ilgili çocukların düşünceleri yaş gruplarına göre değerlendirildiğinde gelişimsel ilerlemenin -bireysel farklılıklar dikkate alınarak- kısmen gözlemlenebildiği söylenebilir.

Tablo 5. Yaş gruplarına göre sorulan sorular ve verilen cevaplar.

\begin{tabular}{|c|c|c|c|c|c|c|}
\hline $\begin{array}{l}\text { Yaş } \\
\text { Gruplan }\end{array}$ & $\begin{array}{l}\text { Niye buraya } \\
\text { geliyorsunuz? }\end{array}$ & $\begin{array}{l}\text { Kur'an ne } \\
\text { demek? }\end{array}$ & $\begin{array}{l}\text { Dua Ne } \\
\text { demek? }\end{array}$ & $\begin{array}{l}\text { Allah'ı seviyor } \\
\text { musunuz? } \\
\text { Allah'a karşı ne } \\
\text { hissediyorsunuz? } \\
\text { Neden? }\end{array}$ & $\begin{array}{l}\text { Allah } \\
\text { deyince } \\
\text { aklınıza } \\
\text { ne/ler } \\
\text { geliyor? }\end{array}$ & $\begin{array}{l}\text { Peygamber } \\
\text { ne demek? }\end{array}$ \\
\hline 4 yaş & $\begin{array}{l}\text { Öğrenmekiçin } \\
\text { Allah için } \\
\text { Kur'an okumak } \\
\text { için } \\
\text { Öğretmeni } \\
\text { görmek için }\end{array}$ & $\begin{array}{l}\text { Dua } \\
\text { Çalışmak } \\
\text { Allah }\end{array}$ & Allah & Bizi oyarattı & $\begin{array}{l}\text { Benim } \\
\text { dedem } \\
\text { öldü } \\
\text { Hızlı } \\
\text { motor } \\
\text { Dua }\end{array}$ & Allah \\
\hline 5 yaş & $\begin{array}{l}\text { Kur'an okumak } \\
\text { için } \\
\text { Kur'an } \\
\text { öğrenmekiçi } \\
\text { Kur'an'a geçmek } \\
\text { için } \\
\text { Aklımızı } \\
\text { çalıştırmak içi }\end{array}$ & $\begin{array}{l}\text { Kur'an'ıAllah } \\
\text { yaratmıştır } \\
\text { Allah } \\
\text { Dua }\end{array}$ & $\begin{array}{l}\text { Kuran'a } \\
\text { benzeyen } \\
\text { bir şey }\end{array}$ & $\begin{array}{ll}\text { Allah'a dua } & \text { du } \\
\text { ediyorum } & \\
\text { Düsünnmedim } & \\
\text { Rabbena } & \\
\text { Rabbi Yessir } & \end{array}$ & & $\begin{array}{l}\text { Namaz kilmak } \\
\text { demek } \\
\text { Allah }\end{array}$ \\
\hline 6 yaş & $\begin{array}{l}\text { Kur'an okumak } \\
\text { için }\end{array}$ & Allah & & O bizim Allah'ımı & $\ldots$ & Allah \\
\hline
\end{tabular}

"Kur'an ne demek?" sorusuna 4 yaş grubu çocuklar "dua, çalışmak, Allah" cevabını vermişlerdir. 5 yaş grubu çocuklar "Kur'an'ı Allah yaratmıştır, Allah, duaya benzeyen şey" cevaplarını vermişlerdir. 6 yaş grubu çocukların ise "Allah" cevabını verdikleri görülmüştür. Çocukların Kur'an ile Allah arasındaki ilişkisel bağı anlayamadıkları ve Kur'an ile Allah’ın aynı olduğu düşüncesine sahip oldukları söylenebilir. Yaşın ilerlemesi ile birlikte çocuklar zihinsel anlamda ilerleme kaydetse de hala Kuran ile ilgili dağınık düşüncelere sahiptir. Çocukların -Kur'an'ı gözleriyle görüp elleriyle tutabildikleri düşünülürse- böylesine somut yaşantılarla öğrenmeye çalıştığı Kur’an ile ilgili hala kafa karışıklığı yaşaması oldukça dikkat çekicidir. Bu durum Kur'an'ın çocuklara soyut olan harfler üzerinden tanıtılması ve 
öğretilmeye çalışımasının yani parçacı yaklaşımın neden olduğu söylenebilir. Anlamlı ve bütüncül yöntemlerle çocukların Kur’an ile karşılaşmalarının gelişimsel açıdan daha doğru bir yaklaşım olduğu söylenebilir.

"Dua ne demek?" sorusuna 4 yaş grubu çocukları "Allah" cevabını vermişlerdir. "Allah deyince aklınıza ne/ler geliyor?" sorusuna da bu yaş grubu dua ile ilişkili olan "hızlı motor, dedem öldü ve dua" cevaplarını vermeleri çocukların Allah ve dua kavramını tutarlı bir şekilde ilişkilendirebildiklerini gösterdiği söylenebilir. 5 yaş grubu çocuklar dua ile ilgili soruya "Kur'an'a benzeyen şey" cevabını vermişlerdir. Yine "hacı dedeme, anneme, babama, nineme, kardeşime" dua ettiğini söyleyen çocuklar duayı iki farklı şekilde anlamaktadırlar. Birincisi ölen yakınına ya da küçük kardeşine öğrettiği-Kur'an'dan -kısasureleri okumak şeklinde dua etmektir. İkincisi ise sevdiği yakınlarının varlığının devamı için iyi dilek, temenni anlamında dua etmektir.

"Allah'a karşı ne hissediyorsunuz?/Allah'ı seviyor musunuz? Neden?" sorusuna 4 yaş grubu "bizi O yarattı” cevabını vermiştir. 5 yaş grubu “Allah'a dua ediyorum, Düşünmedim, Buraya gelince yeni yeni bir şeyler hissetmeye başladım, "Rabbena, Rabbi Yessir" cevabını vermişlerdir. 6 yaş grubu "O bizi yarattı, O bizim Allah'ımız" cevabını vermişlerdir. Çocuklar Allah'ın kendilerini yaratmasından dolayı Allah'a karşı olumlu duygular beslemektedirler. Kursa devam eden bir çocuğun "buraya gelince bir şeyler hissetmeye başladım" cevabı manevi gelişim de çevre faktörünün önemine işaret etmektedir. Çocuklar her ne kadar manevi varlıklar olsalar da (Boyatsiz and Newman, 2004, s. 166) çevrenin etkisi çocuklar üzerinde oldukça yönlendiricidir. Bu alanda yapılan pekçok araştırma göstermiştir ki, aile etkisi dini tutumların oluşmasında en karar verici bir faktördür. Yapılan araştırmalara göre, çocuklarda dini tutumların oluşmasındaki ilk faktör aile eğitimi, sonra bireysel düşünce ve son olarak da okuldur. Sosyolog Wach hangi kültür olursa olsun, yetişkinlerin dini tutumlarının büyük ölçüde onların daha önceleri kendi çevrelerinde özellikle de ailelerinde sahip oldukları dini tecrübeye bağlı olduğunu vurgulamaktadır (Vergote, 1969).

"Peygamber ne demek?" sorusuna 4 yaş grubu "Allah" cevabını vermiştir. 5 yaş grubu "Namaz kılmak demek, Allah, Bilmiyorum" cevabını vermişlerdir. 6 yaş grubu "Allah" cevabını vermişlerdir. Çocukların yaşın ilerlemesine rağmen peygamber ile Allah'ı birbiriyle ilişkilendirdikleri görülmüştür. Bu yanlış ilişkilendirmenin en önemli nedeni çocukların bilişsel anlamdaki düşünme becerilerindeki yetersizliktir. Özellikle peygamber/lerin çocuklar tarafından somut olarak algılanamaması yani görülememesi bu karmaşıklığı daha da arttırmaktadır.

Genel olarak çocukların düşüncelerindeki dağınıklığın döngüsel bir biçimde Allah, Kur'an ve dua etrafında ilerlediği söylenebilir. Çocukların bu kavramları bilişsel düzeyde gerçek anlamı ile anlamamalarından kaynaklı bu dağınıklık, birbirlerini tekrarlayan cevaplara neden olmuştur. Çocukların peygamber kavramına yabancı oldukları görülmüştür. Allah, 
Kur'an ve dua kavramında yaşadıkları hem kavramsal hem ilişkisel kargaşanın doğal bir sonucu peygamber kavramının anlaşılmamasına neden olduğu söylenebilir.

Şekil 1. 4 yaş grubu çocuklarının görüşme sorularına verdikleri cevaplar

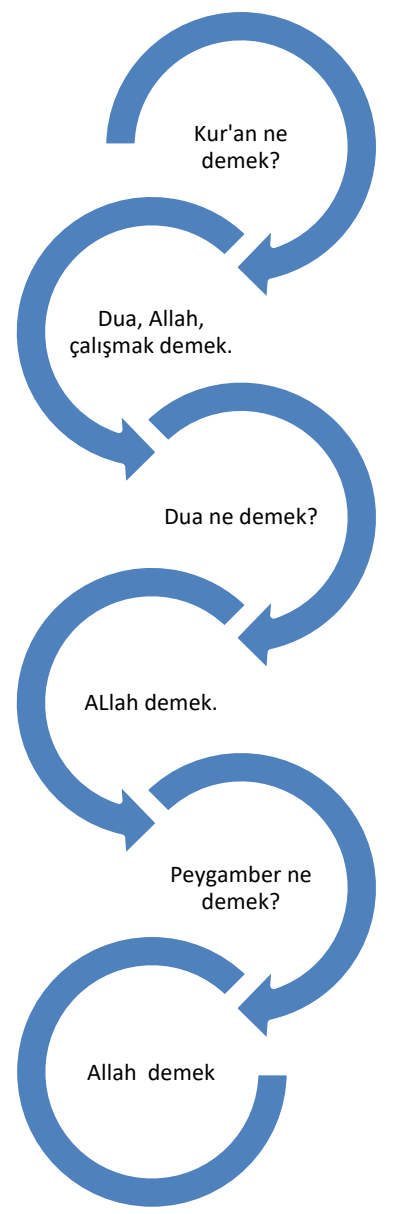

\section{Tartışma ve Sonuç}

Okul öncesi yılları çocuğun temel gelişimsel birçok görevi olgunlaştırması açısından oldukça önemlidir (Barnard, 1978, s. 215). Dini gelişim açısından da dinamik bir zaman dilimi olan bu dönemde başarılı bir din eğitim yürütmek isteniyorsa öğrenme olgusunun mantıki değil, psikolojik olduğu göz önüne alınmalıdır. Yani din öğretimi, dinin mantıki parameterlerine kendini uydurma yerine öğrenen kişinin psikolojik özelliklerine kendisini adapte etmeli ve öğrenen kişinin bireysel özelliklerini dikkate alarak içerik ve yöntem geliştirmelidir (Lee, 1988, s. 167). 
Dini gelişim üzerine yapılan araştırmalar, çocukların genellikle 11-12 yaşlarına gelinceye kadar yetişkinlerin anladığı anlamda dini kavramları anlayamadıklarını ortaya koymaktadır. Örneğin 5-6 yaşındaki bir çocuk için Müslüman, Hıristiyan ya da Yahudi olmanın anlamı yetişkinlerdeki gibi değildir. Daha doğrusu aralarındaki farklılığı bilemez. David Elkind çocukların dini kimlikleriyle ilgili yaptığı araştırmasında aşağıdaki diyaloğu aktarır:

Araştırmacı: "Sen Yahudi misin?"

Lin (5yaş): "Evet."

Araştırmacı: "Ailen de Yahudi mi?"

Lin: “Evet, köpeğimiz hariç, hepimiz Yahudi'yiz, ama köpeğimiz bir Fransız kaniş (kıvırcık tüylü köpek)."

Bu örnekten de anlaşılacağı gibi bu yaştaki çocuklar daha dini mezhebin ya da grubun ne anlama geldiğini ve kimlere ait olduğunu bilemez (Elkind, 1964). Çocuklar altı yaşına kadar dini kavramların anlamlarıyla ilgili çok sınırlı bir bilgiye sahiptirler, özellikle beş yaşına kadar anlayış son derece yüzeyseldir. Dini kavram ve anlama daha çok dış dünyayla alakalı olup, kişisel varlık ve fiziki ihtiyaçların karşılanmasıyla ilişkilidir (Hyde, 1990, s. 99). Bu araştırmada çocukların "Kur'an, Allah, dua ve peygamber" kavramlarını hem kavramsal olarak hem de ilişkisel olarak henüz tam anlayamadıkları görülmüştür.

Çocukluk dönemindeki dua anlayışı gelişimsel olarak üç basamakta gerçekleşmektedir. İlk basamak olan 5-7 yaşları arasında çocuklar müphem ve parçacı bir anlayışla evrensel bir dua fikrine sahiptir (Köylü ve Oruç, 2017, ss. 84-94). Bu basamaktaki çocuklar için duanın bir dereceye kadar Allah kavramıyla ilişkisi kurulabilse de, çocukların verdikleri örneklerden duanın gerçek anlamıyla ilgili fazla bir düşünceye sahip olmadıkları anlaşılmaktadır. Bu dönemdeki çocuklara göre kedi ve köpekler dahil dünyadaki oğlan ya da kız her çocuk dua eder. Bunun da onlara göre çok değişik nedenleri vardır. Beş yaşındaki çocuk için dua, Allah, tavşanlar, köpekler, kediler, geyikler ve hindilerle, bebeklerle ilgili bir şeydir (Elkind, 1967, ss. 102-106). Araştırmada çocukların "Kur'an, Allah, dua ve peygamber" kavramlarını birbirleriyle yanlış ve eksik ilişkilendirmeler içerisinde anladıkları görülse de Allah ile dua kavramı arasında daha doğru bir ilişkilendirme yaptıkları görülmüştür. Bunun çocukların benmerkezci düşünce şeklinden kaynaklanan bir durumun sonucu olduğu söylenebilir. Bu dönemde çocuk kendisi dışındaki şeylerin varlığının anlamını kavrayamamaktadır (Goldman, 1971, s. 28). Her şeye kendisinin bakış açısıyla bakmakta ve her şeyin onun varlığına hizmet ettiğini düşünmektedir. Dolayısıyla dua, bu dönemdeki çocuklar tarafından isteklerine ulaşmada bir araç olarak görülmektedir. Bu yönüyle dua çocukların merak, ilgi ve ihtiyaçları bağlamında karşılığı olduğu için çocuğun hayatında daha somut bir olgu olarak algılanması diğer soyut kavramlara nazaran daha anlaşılır bir durumdur. Ayrıca Müslüman çocuklar açısından duanın Kuran'da ki -kısa- 
sureler ve Allah'tan bir şey istemek anlamında iki farklı şekilde algılandığı da tespit edilmiştir. Sonuç olarak duanın bir dereceye kadar Allah kavramıyla ve öğrenilmiş bazı formüllerle ilişkisi kurabilseler de, yetişkinin anladığı tarzda duanın anlamına dair çok az bir kavrama ve anlayış vardır (Elkind, 1964, ss. 674-675).

Çocukların Tanrı hakkındaki görüşlerine ilişkin çalışmalar 1892'li yıllara kadar ulaşmaktadır. Bununla beraber bu alandaki ciddi araştırmalar Goldman'ın çalışmalarıyla başlamıştır. O dönemden bu zamana birçok çalışma yapılmıştır. İskandinav ülkelerinde yapılan araştırmalarda dört-altı yaş arasındaki çocukların tanrıyı eğlence ve oyunla ilişkilendirdikleri, çocukların iyiliğiyle ilgilenen izin verici bir tanrı anlayışına sahip olduklarını ve kendileri için muayyen birtakım fonksiyonları yerine getiren bir varlık olarak algıladıklarını ortaya koymuştur (Tamminen, 1988, s. 60). Okulöncesi çocuklardan neredeyse hepsi, tanrının gökte olduğunu ve bu yüzden uzaklığı dolayısıyla kendisine ulaşılamadığına ilişkin izahlar getirmeye çalıştıkları bulunmuştur. Diğer taraftan Keskitalo okulöncesi çocuklardan \% 80'inin Tanrıyı kendilerine yakın olduğuna ve diğer çocuklara hatta yetişkinlere yakın olduğuna inandıklarını bulmuştur. Onlardan bazıları tanrı göktedir ve onun yakınlığı sınırlıdır derken, bazıları da onun mekanının gökyüzüyle sınırlı tutulamayacağını, bazen onun gerçek şekline bürünerek yer yüzüne inebileceğini ifade ederken, diğer bazıları da tanrıyı yardımcı birer varlık olarak melekler şeklinde tasavvur etmişlerdir (Tamminen, 1988, ss. 63-64). Bu araştırmada çocukların Allah kavramını, kuran ve dua kavramı ile ilişkilendirdikleri görülmüştür. Allah'ı zihinlerinde nasıl temsil ettiklerini anlamak için sorulan "Allah deyince aklınıza ne/neler geliyor?" sorusuna sadece 4 yaş grubu çocuklar dua ile ilişkilendirilecek cevaplar vermişlerdir. íki çocuk ise rüyasında Allah'ı bulutların üzerinde gördüğünü ifade etmiştir.

Tamminen'ın Finli çocuklarla gerçekleştirdiği çalışmasında, çocukların neredeyse hepsinin tanrının kendilerini sevdiğine ve Tanrının iyi, seven, huzur verici olduğuna inandıklarını çalışmasıyla ortaya koymuştur. Büyük çocukların da Tanrı'yı oldukça olumlu sıfatlarla tasavvur ederlerken, sadece birkaç çocuğun Tanrı'yı bir korku objesi olarak tasavvur ettiklerini belirtmiştir (Tamminen, 1988, s. 63). Birkaç çalışma da bazı küçük çocukların korku verici bir Tanrı imajına sahip olduklarını ortaya koymuştur. Bunlardan Ottersen'ın İsveçli çocuklar üzerine yaptığı araştırmasında dine karşı ya da dine ilgisiz kalan aile ortamlarından gelen çocukların Tanrı hakkında olumsuz imaja sahip olduklarını bu yüzden Tanrı'yı korku ve hüzün verici bir varlık olarak tasavvur ettiklerini ortaya koymuştur. Ancak Tamminen yaptığı araştırmasında altı ve yedi yaşındaki çocuklara "Siz Tanrı hakkında bir şey duyduğunuzda korku, iyilik veya emniyet/huzur ne hissediyorsunuz?" diye sorduğunda, çocuklardan sadece bir tanesi korku hissediyorum derken, bazıları her iki duyguyu duyduklarını, ama aşağı yukarı tamamına yakını iyi şeyler hissettiklerini belirtmişlerdir (Tamminen, 1988, ss. 62-63). Sonuç olarak bu dönemdeki çocuklar genellikle Tanrı'ya ilişkin olumlu duygusal tutumlara sahiptirler. Özellikle Tanrı kendi anlayışlarına uygun oldukça -bilişsel anlamda da ilerleme kaydettikçe- Tanrı'ya güven 
duyguları artmaktadır (Tamminen, 1988, s. 64). Bu araştırmada tüm çocukların Allah karşı sevgi, teşekkür gibi olumlu duygular besledikleri tespit edilmiştir. Bu duyguların sebebinin ise Allah'ın kendilerini yaratması olarak ifade edilmiştir. Sadece bir çocuk kursa geldikten sonra Allah ile ilgili bir şeyler hissetmeye başladığını söylemiştir. Bu durum çocukların maneviyatı yaşaması için ailenin rolünü anlamak açısından oldukça dikkat çekici bir örnektir. Çünkü erken çocukluk döneminde çocuklar ebeveynlerinin model alırlar (Köylü ve Oruç, 2017, s. 121).

Çocukların dini kavramlar hakkındaki düşüncesini bilmek bize din eğitimi programlarına hangi konuların konulup konulmamasında yardımcı olacağı gibi, bu kavramların nasıl öğretileceği konusunda da yardımcı olmakta ve yol göstermektedir (Vianello and Tamminen, and Ratcliff, 1992, ss. 76-77). Bu araştırmada 4-6 yaş grubu çocukların Kuran, Allah ve dua kavramlarıyla ilişkili olarak her ne kadar eksik ve tutarsız da olsa bir düşünce geliştirdikleri görülmüştür. Bununla birlikte bu yaş grubu çocukların peygamber/ler ile ilgili herhangi bir fikir geliştiremedikleri hatta peygamber-Allah ilişkilendirmesi yaptıkları gözlenmiştir. Bu dönemde dini içeriğin önemli konularından olan peygamber/leri anlatmaya başlamadan önce, ileri yaşlarda anlatılabilmesi için "ön hazırlık çalışması" olarak adlandırılabilecek bir çalışmanın yapılmasının daha doğru olduğu söylenebilir. Özellikle çocuklara zihinsel düzeyde peygamber/ler anlatımından daha ziyade çocuklara din eğitimi veren kişilerin sevdiği/örnek aldığı bir rehber olarak peygamber/lere duyulan sevginin ön plana çıkarıldığı ve çocuklar tarafından gözlemlenebileceği kurgular oluşturulmalıdır. Çünkü her şeyden önce çocuklara dinin bilişsel/kognitif boyutu yerine sevgi boyutu, tecrübe ve yaşamsal boyutu öğretilmeye çalışılmalıdır. Zira insan hayatının dört boyutu vardır: bunlar psikomotor, bilişsel, duygusal ve yaşam tarzı şekilleri. Kişi ancak bu dört unsuru birlikte yaşarsa hayatının bir anlamı olur ve eksik kalmaz. Aynı zamanda bu dört unsur etkili bir din eğitiminin merkezini oluşturur (Lee, 1988, s. 154). Bunlardan en önemlisi yaşam tarzı, sonraki duygular (affects) bilişsel ve en az önemli olan da psikomotordur. Çocukluk dönemi din için sevgi bilişsel nitelikten çok daha önemlidir. Gerçekten de birçok araştırmacıyla birlikte özellikle derinlik psikolojisi üzerine araştırma yapan kişiler tutum, değer ve sevgi temelli duyguların (aslında tüm duyguların) altı yaşından önce öğrenileceğini öne sürmektedirler (Lee, 1988, s. 154).

Elkind de din eğitimi açısından şu değerlendirmeyi yapmaktadır. Çoğu çocuklar ergenlik öncesi döneme kadar dini ifadeleri tam olarak anlayamazlar ancak kendi anlayış seviyeleri çerçevesinde yorumlayabilirler. O zaman şu soru ortaya çıkmaktadır: "Hatalı sonuçlara ulaşmamak için bu dönemdeki çocuklar din eğitimine tabii tutulmamalı mıdırlar?". Elkind soruyla ilgili olarak bu dönem çocuklarına zihinsel ya da akademik boyutta din eğitimi yerine yani çocukların zihnine hitap etme yerine hislerine hitap etmenin daha önemli olduğunu, gerçek dini eğitimin de zihin kadar hisleri ve duyguyu beslediğini öne sürmektedir. Sonuç olarak, çocuk dini düşünceleri kabul etmeden dini hisleri tecrübe etmelidir (Elkind, 1964, ss. 635-646). Elbette bu dönemde çocukları Tanrı, peygamber, 
Kuran, dua gibi dini kavramlarla ilgili basit ifadeleri öğrenme kapasiteleri dahilindedir. Bu anlatımların çocuklar tarafından anlaşılır ve kısa olması şartıyla kolayca ezberlenebilir ve tekrar da edebilir. Ancak bu dönem çocuklarına birşeyler öğretirken şu hususları da göz önünde bulundurmamız gerekir: 1) Soyut kavramları anlayamazlar, 2) Çok uzun olan ve sayıca fazla olan gerçekleri hatırlayamazlar, 3) Kutsal metinden uzun ayetler ezberleyemezler, 4) Öğrenecekleri dua ve sureler kısa olmalıdır (Barnard, 1978, s. 218).

Okulöncesi çocuklara öğretilebilecek en temel şey Allah kavramıdır (Torrance ve Torrance, 1988, s. 233). Doğal olarak çocuklara doğru ve gerçekçi bir Allah kavramı öğretmeksizin diğer dini konularda bir şeyler öğretmeye kalkışmak zaman israfıdır. O yüzden de önce çocuklara doğru bir Allah kavramının öğretilmesi gerekmektedir (Torrance ve Torrance, 1988, s. 234). Bu durum aynı zamanda dua, kuran ve peygamber kavramlarının anlatılması için de oldukça gerekli ve önemlidir. Özellikle bu kavramların birbirleriyle ilişkisinin anlamlı, somuttan soyuta, basitten karmaşığa, yakından uzağa öğretim ilkeleri çerçevesinde (Senemoğlu, 2012) çocuğun anlayacağı bir içerik ile sunulması din eğitiminin pedagojik yönünü oluşturması açısından oldukça önemlidir.

Küçük çocuklar sadece kendilerine öğretilen dini öğrenmezler aynı zamanda dini kendilerine öğretilen şekil ya da yol açısından da öğrenirler. Eğer çocuğa din sevgi boyutuyla değil de daha çok Allah'ın adaletinin hukuki karakteri öğretilmeye çalışılırsa, o takdirde çocuğun dini bilgilerden elde edeceği içerik sevgi dışı hukuki (legalistic) bir din olacaktır. Aslında, öğretilen bir şeyin öğretim tarzı genellikle öz olarak öğretilen şeyin kendisinden daha çok öğrenen üzerine bilişsel ve tutumsal etki yaratır. Gerçekte dini öğretme şekli ya da öğrenme şekli aslında öğretilen dindir. Öğretim süreçleri dini öğretinin güçlü bir içeriğini teşkil eder (Lee, 1988, ss. 152-153). Dolayısıyla çocukların din eğiticileri nitelikli ve etkili öğretim strateji, yöntem ve tekniklerine sahip olması gerekir. Diğer bir ifadeyle din sadece bilişsel açıdan öğretilmemeli aynı zamanda duygusal ve daha çok hayat tarzı içeriği göz önüne alınarak öğretilmelidir. Bu alanda yapılan araştırmalar da çocukların en çok duygu boyutunda yetişkinlere benzediğini en az da bilişsel alanda onlara benzediğini ortaya koymuştur (Lee, 1988, s. 162).

Psikolojik olarak küçük çocuklar "bireysel ilişkiler yoluyla" öğrenirler. Öğrenen kişi ile bireysel ilişkilerin kurulması erken çocuklukta çok daha hayati bir nitelik taşımaktadır. Çünkü küçük çocuklar daha yoğun duygusal derinlikte ve bütünlükçü/holistik insan etkileşimleri içinde hayatı anlamlandırırlar. Oysa yetişkinler bireysel ilişkilerden kaçınmak ve yaklaşmak istemediklerinde bilişsel yeteneklerini ve savunma mekanizmalarını kullanırlar. Dolayısıyla eğiticinin sempatik bir sesi, sevgi dolu kalbi ve dokunuşu çocuğun din eğitimi için son derece önemli olan hususlardandır. Çünkü "duygu/lar çocuğun tüm öğrenmelerinde olağanüstü güçlü bir faktörü teşkil eder". Bu prensip önceki prensibin daha özel bir uzantısıdır, zira kişisel ilişkiler daima ağılıklı olarak duygusaldır. Kişiliğin duygusal yönü, şöyle ki duygusal alanı, ilk çocukluk döneminde en hâkim olan unsurdur. Gerçekten de duygular öğrenilir ve duygular gelişen bireyde bilişsel ve isteğe bağlı 
eylemlerden önce gelir. Bu durum bizi iki önemli psikolojik sonuca götürmektedir. Bunlardan birincisi, duygu daha sonra kendisinde ve kendisi yoluyla şekillendireceği kognitif ve gönüllü eylemi kişinin temel psikolojik yapısını güçlü bir şekilde renklendirir ve örgüsünü oluşturur (Lee, 1988, ss. 168-169). “Öğrenme çevresinin sosyoduygusal iklimi de önemli derecede öğrenme sonuçlarına etki eder." Her şeyden önce şunu kabul etmek gerekir ki, pedagojik ortamdaki sosyoduygusal iklim sadece duygusal öğrenme sonuçlarını değil aynı zamanda bilişsel öğrenme sonuçlarını da etkileyecektir. Bu prensip daha önce zikrettiğimiz iki prensibin bir uzantısıdır. Sosyoduygusal iklim okulöncesi çocuklarının tüm öğrenme ortamlarında özellikle de dini öğrenme ortamlarında önemli olup, temelini de sevgi oluşturmaktadır. Sevgi de ihtimamı, şartsız kabulü, sıcaklığı, vermeyi, affetmeyi vs. içerir. Sosyoduygusal atmosferin duygu boyutu iki yönlü bir yol gibidir, çocuk hem sevmeye hem de sevilmeye ihtiyaç duymaktadır. İşte böyle bir ortamda okulöncesi çocuklara kazandırılacak en büyük dini değer ve öğreti Allah sevgisi olacaktır. Öğretme ve öğrenme ortamındaki sevgi dinamiği olmaksızın, küçük çocuk dini içten benimseyen ve ona bağımlı olacağı yerde dine karşı antipatisi olacak şekilde yetiştirilebilir. Hatta daha ileri boyutta sevgiden yoksun bir din eğitimi çocukların sadece dinden soğumasına ya da dine karşı ilgisiz kalmasına değil, dini tamamen reddetmesine ve ona karşı gelmesine bile neden olabilir. Yine bu dönemdeki çocuklara Allah sevgisinden uzak doğru ve yanlış şeyleri öğretmek de istenen sonucu vermez. Kısacası tüm dini bilgiler, doğru ve yanlış kavramları ve diğer ahlaki erdemler zihinsel, entelektüel temel esasından ziyade sevgi esasına dayandırılarak öğretilmeye çalışılmalıdır (Lee, 1988, ss. 169-171).

\section{Öneriler}

1. Din eğitimi, çocuğun psikolojik özelliklerini dikkate alarak içeriklerini üretmelidir. Dini açıdan önemli olan konular/içeriklerden ziyade çocuğun dini gelişimini destekleyecek konular/içerikler din eğitimine dâhil edilmelidir.

2. Çocuklar bilişsel anlamda dini kavramlarla ilgili erken çocukluk döneminde oldukça yüzeysel düşüncelere sahiptirler. Dini gelişim diğer gelişim alanlılarındaki ilerlemeler oranında gerçekleşeceği için Allah, dua, peygamber, kuran gibi soyut dini kavramlarla ilgili de düşünme kapasiteleri oldukça sınırlıdır. Dolayısıyla bu dönemde planlanacak din eğitiminde bu durum göz önüne alınmalıdır. Dâhil edilmesi planlanan konuların salt bilişsel yönleri yerine duygu, tutum ve davranış geliştirmeye yönelik yönleri ele alınmalıdır.

3. Erken çocukluk döneminde duygular çocuk için çok önemlidir. Zihinsel yeterliliklerin gelişim aşamasında olmasından dolayı da din eğitimi, çocukta oluşturması beklenen/istenen duyguları kendisine başlangıç noktası yapmalıdır.

4. Çocuklar kişiler arası ilişkilerle öğrenirler. Öğrenme ortamının çocukta oluşturacağı duygu erken çocukluk döneminde daha kritik bir önem taşır. Bu dönemde anlatılması planlanan konuların bilişsel detaylarından daha çok nasıl 
bir ortam içerisinde ne şekilde öğretilmesine yani içerikten ziyade yöntem ve tekniğine odaklanılmalıdır.

5. Din eğitiminde ele alınan konular temel sevgi duygusu etrafında çocuğa verilmelidir.

\section{Kaynakça}

Akturan, U. \& Esen, A. (2008). Nitel araştırma yöntemleri. Ankara: Seçkin Yayıncılık.

Boyatzis, C. J. \& Newman, B. T. (2004). How shall we study children's spirituality?. (ed. Donald Ratcliff), Children's Spirituality: Christian Perspectives, Research, and Application, (ss. 166-181), Or: Cascade Books.

Boojamra, J. L. (1984). Theological and pedagogical perspectives on the family as educator. The Grek Orthodox Theological Review, 29(1), (Spring 1984).

Bunge, M. J. (2006). The child, religion, and the academy: developing robust theological and religious understanding of children and childhood, The Journal of Religion.

Coles, R. (1990). The spiritual life of children-the inner lives of children, Boston: Houghton Mifflin Company.

Copley, T. (2008). Teaching religion-sixty years of religious education in england and wales. Exeter: University of Exeter Press.

Cox, E. (1966). Changing aims in religious education, London: Routledge and Kegan Paul, 1966.

Elkind, D. (1964). The child's conception of his religious identity. Lumen Vitae: International Review of Religious Education, vol 19.

Elkind, D. (1967). The child's conception of prayer. Journal for the Scientific Study of Religion, 6(1).

Elkind, D. (1970). The origins of religion in the child. Review of Religious Research, 12(1), (Autumn).

Elkınd, D. (1971). The development of religious understanding in children and adolescent. Research on Religious Development: A Comprehensive Handbooks. Metron P. Strommen (ed.). ss.655-685. New York: Hawthorn Books.

Elmalılı M. Hamdi Yazır, Hak dini Kur'an dili. (C. 7). İstanbul: Azim Dağıtım, trs.

Erıkson, E. H. (1963). Childhood and society (2nd ed.). New York: Norton.

Ersoy, A. \& Saban, A. (2019). Eğitimde nitel araştırma desenleri. Ankara: Anı. 
Fraenkel, Jack R., Norman E. Wallen, Helen H. Hyun. (2012). How to design and evaluate research in education. New York: McGraw-Hill.

Fowler, J.W. (1974). Toward a developmental perspective on faith. Religious Education. 69:2, 1974.

Fowler, J. W. (2004). Faith development at 30: Naming the challenges of faith in a new millennium. The Official Journal Of The Religious Education Association 99(4).

Fowler, J. W. ve Dell, M. L. (2006). Stages of faith from infancy through adolescence reflections on three decades of faith development theory. The Handbook of Spiritual Development in Childhood and Adolescence. Eugene C. Roehlkepartain, Pamela E. King, Linda Wagener, Peter L. Benson (ed.) SAGE Publications, California.

Goldman, R. (1963). The development of religious thinking. Learning for Living 5(2).

Goldman, R. (1964). Religious thinking from childhood to adolescence. New York: The Seabury Press.

Goldman, R. (!971). Readiness for religion: a basis for developmental religious education. New York: Seabury Press.

Gottlıeb, E. (2012). Dini düşüncenin gelişimi. C. Osmanoğlu, \& M. Ulu. (Çev.) Dinbilimleri Akademik Araştırma Dergisi, 12(1), 269-289.

Harms, E. (1944). The development of religious experience in children. The American Journal of Sociology, 50(2). The University of Chicago Press, September.

Havighurst, R. J. ve Keating,B. (1971). The religion of youth. Research on Religious Development: A Comprehensive Handbooks. Metron P. Strommen (ed.), 686-723. New York: Hawthorn Books.

Heller, D. (1986). The children's god. Chicago: The University of Chicago Press.

Hyde, K. E. (1990). Religion in childhood and adolescence. Birmingham, Alabama: Religious Education Press, 1990.

Köylü, M. ve Oruç, C. (2017). Çocukluk dönemi din eğitimi. Ankara: Nobel.

Lee, J. M. (1988). How to teach: foundations, processes, procedures. Handbook of Preschool Religious Education içinde. ss. 152-223. Donald Raecliff (ed.). Birmingham, Alabama: Religious Education Press.

Leitch, R. (2008). Creatively reserching children's narratives through images and drawings. Doing visual reserch with children and young people içinde. ss. 37-57. P. Thomson (Ed.), NewYork: Routledge. 
Montessori, M. (1965). The child in the church. E.M. Standing (ed.). St. Paul, MN: Catechetical Guild.

Moustakas, C. (1994). Phenomenological reserch methods. London: Sage.

Senemoğlu, N. (2012). Gelişim öğrenme ve öğretim - kuramdan uygulamaya. Ankara: Pegem Akademi.

Oruç C. (2013). Erken çocukluk dönemi dini gelişim teorileri bağlamında din eğitimi. Turkish Studies, 8(8), 971-987.

Oruç, C. (2014). Okul öncesi dönemde çocuğun din eğitimi. İstanbul: Dem Yayınları.

Oruç C. (2019). Tanımı, metodolojisi ve eğitimi açısından çocuk maneviyatı. Din Eğitiminde Çağdaş Konular. Mustafa Köylü (ed.). İstanbul: Dem Yayınları.

Patton, M. Q. (2002). Qualitative research \& evaluation methods (3rd ed.). Thousand Oaks, CA: Sage Publications

Peker, H. (1993). Din psikolojisi. Samsun: Sönmez Matbaa ve Yay.

Riccards, M. P. (1978). The structure of religious development: empirical evidence for a stage theory. Lumen Vitea International Review of Religious Education, 33(1).

Robert W. Crapps, R. W. (1986). An introduction to psychology of religion. Merger Press.

Schweitzer, F. (2006). Children as theologians: god-talk with children, developmental psychology, and inter-religious education. Education, Religion and Society: Essays in Honour of John M. Hull içinde. Dennis Bates vd. (ed.) London: Routledge.

Roos S. A.,Ledema, J. ve Miedema, S. (2003). Effects of mothers' and schools' religious denomination on preschool children's god concepts. Journal of Beliefs \& Values: Studies in Religion \& Education, 24(2).

Tamminen, K., Vianello, R., Jaspord, J. M. ve Ratcliff, D. (1988). The religious concepts of preschoolers. Donald Ratcliff (ed.). Handbook of Preschool Religious Education. Birmingham, Alabama: Religious Education Press.

Thomas Barnard vd., Exploring christian education. Kansas City, Missouri, Beacon Hill Press.

Torrance, E. P. ve Torrance, J. P. (1988). Creativity and teaching concepts of god. Handbook of Preschool Religious Education içinde. ss. 224-246. Donald Raecliff (ed.). Birmingham, Alabama: Religious Education Press.

Vergote, A. (1969). The religious man: A psychological study of religious attitudes. Translated by Marie-Bernard Said. Dayton, $\mathrm{OH}$ : Pflaum Press. 
Vianello, R., Kalevi Tamminen, K. ve Ratcliff, D. (1992). The Religious Concepts of Children. Handbook of Children's Religious Education içinde. ss. 56-81. Donald Raecliff (ed.). Birmingham, Alabama: Religious Education Press.

Wallinga, C. ve Skeen, P. (1988). Physical, Language, and Social-Emotional Development. Handbook of Preschool Religious Education içinde. Donald Raecliff (ed.). Birmingham, Alabama: Religious Education Press.

Wilson, V. (1991). Infant and preschoolers. Christian Education: Foundations for the Future içinde. Robert E. Clark, Lin Johnson and Allyn K. Sloat (ed.). ss. 221-231. Chicago: Mooddy Press.

Yıldırım, A. ve Şimşek, H. (2006). Sosyal bilimlerde nitel araştırma yöntemleri. Ankara: Seçkin Yayıncılık.

Yıldız, M. (2007). Çocuklarda tanrı tasavvurunun gelişimi. İzmir: İzmir İlahiyat Vakfı Yayınları. 